\title{
ANALISIS PENGARUH NON-TARIFF MEASURES EKSPOR KOMODITI CRUDE PALM OIL (CPO) INDONESIA KE NEGARA TUJUAN EKSPOR UTAMA
}

\author{
Ayu Renita Sari', Dedi Budiman Hakim², Lukytawati Anggraeni \\ ${ }^{1}$ Staf pada Kementerian Perdagangan dan Mahasiswa Magister Program Studi Ilmu \\ Ekonomi, FEM IPB \\ ${ }^{2}$ Staf Pengajar FEM IPB
}

Artikel diterima Maret 2014

Artikel disetujui untuk dipublikasikan Desember 2014

\begin{abstract}
The study of this paper is aimed to evaluate the effects of non-tariff measures (NTM) upon Indonesian crude palm oil (CPO) export in the main destinations. Identified the competitiveness analysis using the Revealed Comparative Advantage index and the impact of the measures has estimated using a panel data gravity model constructed with disaggregated data about bilateral export trade flow of crude palm oil between Indonesia and its main trade partners for the period from 2003 to 2013. NTM represented binary variable that specified with a dummy variable. The gravity model has estimated with a fixed effects model and the results indicated that the existence of trade barriers to trade (TBT) appears to impede the Indonesian exports of CPO. But the existence of sanitary and phytosanitary measures (SPS) which related to food safety and the existence of trade remedy (antidumping, subsidy, safeguard) presented a positive impact upon the Indonesian exports of $\mathrm{CPO}$.
\end{abstract}

Keywords: Export, Non-Tariff Measures (NTM), Sanitary and Phytosanitary (SPS), Trade Barriers to Trade (TBT), Trade Remedy, Crude Palm Oil

\section{PENDAHULUAN}

Sejak berdirinya World Trade Organization (WTO) pada tahun 1995 dan adanya liberalisasi dalam perdagangan, negara-negara anggota WTO sepakat untuk menurunkan bea masuk terhadap produk-produk impor yang masuk ke negara mereka bahkan sampai dengan nol persen. Namun ternyata tidak menghilangkan hambatan dalam perdagangan dan memberikan kelancaran arus barang di antara negara-negara tersebut. Hal ini disebabkan masing-masing negara anggota WTO masih berupaya melindungi pasar dalam negerinya dan menghindari persaingan dengan produk impor. Upaya perlindungan tersebut diterjemahkan ke dalam berbagai kebijakan yang justru menjadi hambatan perdagangan baru (Kementerian Perdagangan 2012).

Dalam pengertian luas, hambatan perdagangan diartikan sebagai suatu bentuk tindakan (measures) yang mempengaruhi dan membatasi aliran bebas barang dan jasa dalam perdagangan internasional. Dalam pengertian yang lebih sempit, hambatan perdagangan merupakan suatu bentuk tindakan (measures) yang diterapkan oleh suatu negara yang tidak 
sesuai dengan aturan internasional. Dalam praktek perdagangan internasional, hambatan perdagangan dibagi menjadi hambatan tarif dan hambatan non tarif.

Adanya batasan tarif yang diberlakukan dalam perdagangan, menyebabkan banyak negara melakukan tindakan/kebijakan non tarif. Salah satu tujuan dari kebijakan non tarif atau non-tariff measures (NTM) adalah sebagai proteksi pada produsen domestik dalam menghadapi persaingan impor dengan produk asing. Penerapan NTM akan berdampak pada penurunan ekspor negara-negara yang melakukan perdagangan, sehingga akan mengurangi volume perdagangan serta akan menimbulkan potensial ekspor yang hilang (ITC 2012).

Sejak awal, sektor pertanian telah menjadi perhatian utama dalam negosiasi perdagangan WTO (Agreement on Agriculture/AoA) karena sifatnya yang strategis. Indonesia mempunyai keunggulan dan potensi sebagai negara agraris dengan banyaknya masyarakat yang bekerja pada sektor pertanian. Kontribusi sektor pertanian memiliki peranan penting dalam kegiatan perekonomian di Indonesia, dapat dilihat dari Produk Domestik Bruto (PDB) sebesar 14,43\% pada tahun 2013 dan menempati urutan kedua setelah sektor industri pengolahan (industri non migas) (BPS 2014). Pada saat krisis ekonomi, sektor pertanian merupakan sektor yang cukup kuat menghadapi goncangan ekonomi dan dapat diandalkan dalam pemulihan perekonomian nasional. Salah satu sektor pertanian yang menjadi keunggulan Indonesia adalah subsektor perkebunan khususnya komoditi kelapa sawit.

Buah kelapa sawit terdiri dari daging dan biji. Daging kelapa sawit akan diolah menjadi minyak kelapa sawit mentah atau crude palm oil (CPO), sedangkan bijinya akan diolah menjadi minyak inti sawit atau palm kernel oil (PKO). Pengolahan tersebut dilakukan dalam beberapa tahap yaitu penimbangan, sortasi, pengumpulan buah, perebusan (sterilisasi), penebahan, pelumatan, penempaan, pengutipan minyak, pemurnian minyak dan penyimpanan minyak mentah berupa CPO. Oleh karena itu, CPO termasuk ke dalam produk pengolahan kelapa sawit. Selama bertahun-tahun, produksi minyak sawit global dan rantai pasokan telah dikembangkan, memasok minyak sawit dan turunannya ke berbagai industri dan konsumen (van Gelder 2004). Terdapat peningkatan permintaan secara signifikan dari waktu ke waktu, jumlah besar minyak sawit dikonsumsi di seluruh dunia, didistribusikan di seluruh dunia untuk berbagai produsen sebagai bahan untuk produk konsumen yang tak terhitung jumlahnya, seperti produk makanan, deterjen dan kosmetik, bahan kimia serta pakan ternak.

Crude palm oil (CPO) merupakan salah satu komoditi hasil perkebunan sebagai salah satu komoditi ekspor Indonesia yang cukup penting sebagai penyedia bahan baku bagi sektor industri, penyerap tenaga kerja dan penghasil devisa. Industri berbasis kelapa sawit berkontribusi signifikan terhadap kesejahteraan dalam hal pendapatan dan aset. Selain itu, peranannya membantu perekonomian Indonesia cenderung meningkat dari tahun ke tahun dilihat dari perkembangan ekspor CPO. Saat ini Indonesia merupakan negara produsen sekaligus eksportir CPO terbesar di dunia (USDA 2013).

Pada Gambar 1 dapat diketahui bahwa nilai ekspor CPO Indonesia dan turunannya selama periode 2004-2013 rata-rata mengalami kenaikan setiap tahunnya, namun pada tahun 2009 dan 2013 mengalami penurunan. Menurut data Kementerian Pertanian, sepanjang tahun 2013 ini terjadi penurunan harga CPO dunia. 


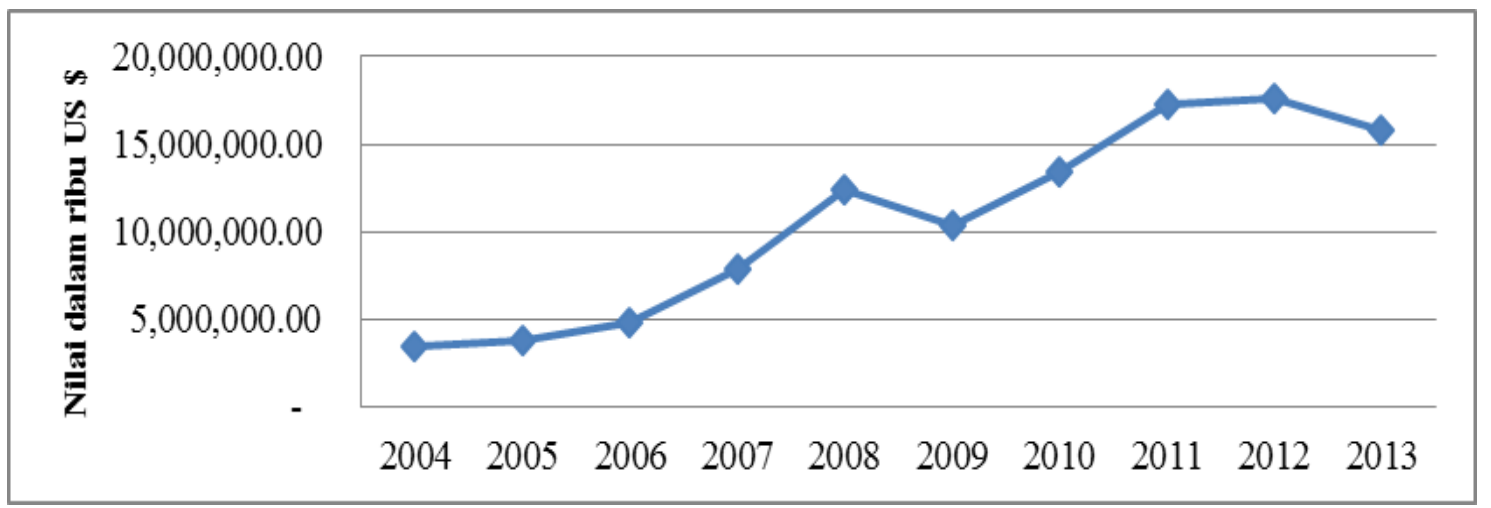

Sumber: UN COMTRADE, 2014

Gambar 1 Ekspor Komoditi CPO Indonesia dan Turunannya ke Dunia

Pada Tabel 1 dapat dilihat bahwa negara tujuan utama ekspor CPO Indonesia adalah India, Uni Eropa, Cina, Malaysia, dan negara tujuan ekspor lainnya. Nilai ekspor komoditi CPO Indonesia ke India pada tahun 2012 sebesar US\$ 4,84 milyar turun menjadi US\$ 4,28 milyar pada tahun
2013, kemudian ekspor ke Cina pada tahun 2012 sebesar US\$ 2,59 milyar juga turun menjadi US\$ 1,79 milyar pada tahun 2013 . Tren nilai ekspor dari tahun 2012-2013 cenderung mengalami penurunan dan di beberapa negara tujuan ekspor menunjukkan nilai yang negatif.

Tabel 1 Negara-negara Tujuan Ekspor Utama Komoditi CPO Indonesia dan Turunannya (Nilai dalam ribu US\$)

\begin{tabular}{|c|c|c|c|c|c|c|c|c|c|}
\hline No. & $\begin{array}{l}\text { Negara } \\
\text { tujuan } \\
\text { ekspor }\end{array}$ & 2009 & 2010 & 2011 & 2012 & 2013 & $\begin{array}{c}\begin{array}{c}\text { Trend } \\
(\%)\end{array} \\
2009- \\
2013\end{array}$ & $\begin{array}{c}\begin{array}{c}\text { Trend } \\
(\%)\end{array} \\
2011- \\
2013\end{array}$ & $\begin{array}{c}\begin{array}{c}\text { Trend } \\
(\%)\end{array} \\
2012- \\
2013\end{array}$ \\
\hline 1 & India & $3,339,967$ & $4,340,215$ & $5,256,449$ & $4,838,414$ & $4,281,590$ & 6.24 & -9.75 & -11.51 \\
\hline 2 & Uni Eropa & $1,861,006$ & $2,171,735$ & $2,154,473$ & $2,372,884$ & $2,577,549$ & 7.68 & 9.38 & 8.63 \\
\hline 3 & Cina & $1,628,648$ & $1,866,513$ & $2,109,518$ & $2,599,993$ & $1,794,127$ & 5.39 & -7.78 & -30.99 \\
\hline 4 & Malaysia & 719,443 & $1,210,757$ & $1,602,954$ & $1,320,836$ & 372,765 & -11.56 & -51.78 & -71.78 \\
\hline 5 & Singapura & 392,602 & 565,577 & 782,521 & 905,281 & 650,147 & 15.94 & -8.85 & -28.18 \\
\hline 6 & Banglades & 527,923 & 626,734 & 885,753 & 706,137 & 501,770 & 0.18 & -24.73 & -28.94 \\
\hline 7 & Pakistan & 139,938 & 81,160 & 296,846 & 714,274 & 814,450 & 76.78 & 65.64 & 14.02 \\
\hline 8 & Mesir & 325,373 & 409,238 & 841,271 & 462,601 & 563,799 & 13.00 & -18.14 & 21.88 \\
\hline 9 & Ukraina & 199,660 & 300,103 & 338,750 & 346,489 & 443,265 & 18.99 & 14.39 & 27.93 \\
\hline 10 & Iran & 141,327 & 277,439 & 326,556 & 191,035 & 251,454 & 8.10 & -12.25 & 31.63 \\
\hline 11 & Rusia & 24,820 & 201,496 & 321,656 & 303,164 & 306,570 & 72.22 & -2.37 & 1.12 \\
\hline 12 & Myanmar & 77,921 & 129,303 & 147,148 & 112,360 & 252,329 & 24.73 & 30.95 & 124.57 \\
\hline 13 & Afrika Selatan & 88,245 & 147,033 & 166,857 & 194,833 & 183,971 & 19.13 & 5.00 & -5.58 \\
\hline 14 & Turki & 40,836 & 49,005 & 81,022 & 208,628 & 215,288 & 61.18 & 63.01 & 3.19 \\
\hline 15 & Vietnam & 129,306 & 160,477 & 160,808 & 130,423 & 74,034 & -12.39 & -32.15 & -43.24 \\
\hline 16 & Tanzania & 77,614 & 95,050 & 259,675 & 180,043 & 125,065 & 17.27 & -30.60 & -30.54 \\
\hline 17 & Arab Saudi & 152,671 & 27,659 & 63,856 & 212,494 & 185,164 & 27.44 & 70.29 & -12.86 \\
\hline 18 & Brazil & 61,894 & 128,330 & 177,676 & 147,521 & 148,092 & 20.73 & -8.70 & 0.39 \\
\hline 19 & Jordania & 25,767 & 12,253 & 5,709 & 16,263 & 11,990 & -11.72 & 44.92 & -26.27 \\
\hline 20 & $\begin{array}{l}\text { Amerika } \\
\text { Serikat }\end{array}$ & 67,265 & 32,899 & 33,015 & 38,548 & 297,440 & 36.77 & 200.15 & 671.61 \\
\hline 21 & Sri Lanka & 3,673 & 9,707 & 29,622 & 10,624 & 23,092 & 45.75 & -11.71 & 117.36 \\
\hline
\end{tabular}

Sumber: TRADE MAP, diolah 2014

Pada tahun 1990-an telah terjadi ekspansi besar-besaran perkebunan kelapa sawit di Indonesia dilakukan pada masa pemerintahan Presiden Suharto, perluasan perkebunan kelapa sawit ini berlanjut hingga pemerintahan Presiden Susilo Bambang Yudhoyono. Kelapa sawit dianggap sebagai tanaman penghasil minyak (CPO) yang paling efisien dan sangat produktif dibandingkan dengan 
tanaman penghasil minyak lainnya. Menurut Hai (2004), kelapa sawit hanya membutuhkan 0,3 ha untuk menghasilkan 1 ton minyak sementara kedelai, bunga matahari dan rapeseed membutuhkan 2,17 ha, 1,52 ha dan 0,75 ha untuk menghasilkan jumlah yang sama. Kelapa sawit menghasilkan tujuh kali hasil minyak per hektar lebih tinggi dari kedelai, lima kali lebih tinggi dari bunga matahari dan 2,5 kali lebih tinggi dari rapeseed. Dengan keunggulan komparatif ini, CPO juga sedang dipromosikan sebagai salah satu masukan penting untuk produksi biodiesel, dan dengan demikian merupakan sumber energi alternatif untuk bahan bakar fosil (Hai 2004).

CPO merupakan komoditas yang mempunyai nilai strategis, karena sebagai bahan baku pembuatan minyak makan yang merupakan salah satu dari sembilan kebutuhan pokok bangsa Indonesia. Kebutuhan minyak nabati dan lemak dunia juga terus meningkat sebagai akibat dari pertumbuhan penduduk. Dengan permintaan global dan domestik yang terus meningkat yang ditunjukkan dengan tren kenaikan permintaan CPO untuk bahan bakar nabati selain fungsi tradisionalnya untuk bahan pangan, sehingga diperlukan praktik agribisnis yang berkelanjutan.

Namun, akibat adanya ekspansi besar-besaran tersebut kemudian muncul kampanye negatif dari LSM (lembaga sosial masyarakat) lingkungan hidup internasional, yang menyoroti isu pelanggaran lingkungan. Pada tahun 1990-an lalu CPO juga diterpa oleh isu produk yang mengganggu kesehatan karena diduga mengandung lemak jenuh dan kolesterol tinggi. Produk-produk minyak nabati (seperti minyak bunga matahari, minyak kedelai, rapeseed oil, dan sebagainya) pesaing kelapa sawit tak mampu berkompetisi dengan produk minyak sawit. Pada tahun 2010 volume perdagangan CPO di dunia mencapai $34 \%$ dari volume dunia, padahal di era tahun 1990-an pasarnya hanya $10 \%$.

Dengan adanya ekspansi besar-besaran dan munculnya kampanye negatif tersebut maka diformulasikan menjadi suatu regulasi yang sifatnya menghambat perdagangan. Selain itu dalam beberapa tahun belakangan ini tren nilai ekspor CPO cenderung mengalami penurunan dan di beberapa negara tujuan ekspor menunjukkan nilai yang negatif. Banyak negara terutama negara maju yang memproteksi industri domestiknya dengan memberlakukan kebijakan atau regulasi NTM yang berpeluang untuk menjadi non-tariff barrier yang dapat menghambat masuknya suatu produk ke negara tujuan ekspor. Oleh karena itu, upaya menembus pasar ekspor CPO pun masih mengalami hambatan dari negara tujuan ekspor khususnya NTM yang berpotensi akan merugikan kepentingan perdagangan Indonesia. Akibatnya, industri CPO akan kesulitan melakukan ekspansi dan atau mengalami penurunan daya saing jika hambatan tersebut tidak dihilangkan.

Menurut UNCTAD (2013) definisi dari non-tariff measures (NTM) adalah kebijakan-kebijakan selain tarif yang secara potensial dapat memiliki pengaruh ekonomi pada perdagangan komoditi internasional, dengan mengubah kuantitas perdagangan atau harga atau keduanya. Pada Gambar 2 terdapat klasifikasi NTM yang secara garis besar dibagi menjadi 2 (dua) bagian pokok yaitu import measures (berupa technical measures dan non technical measures) serta export measures (berupa export related measures). 


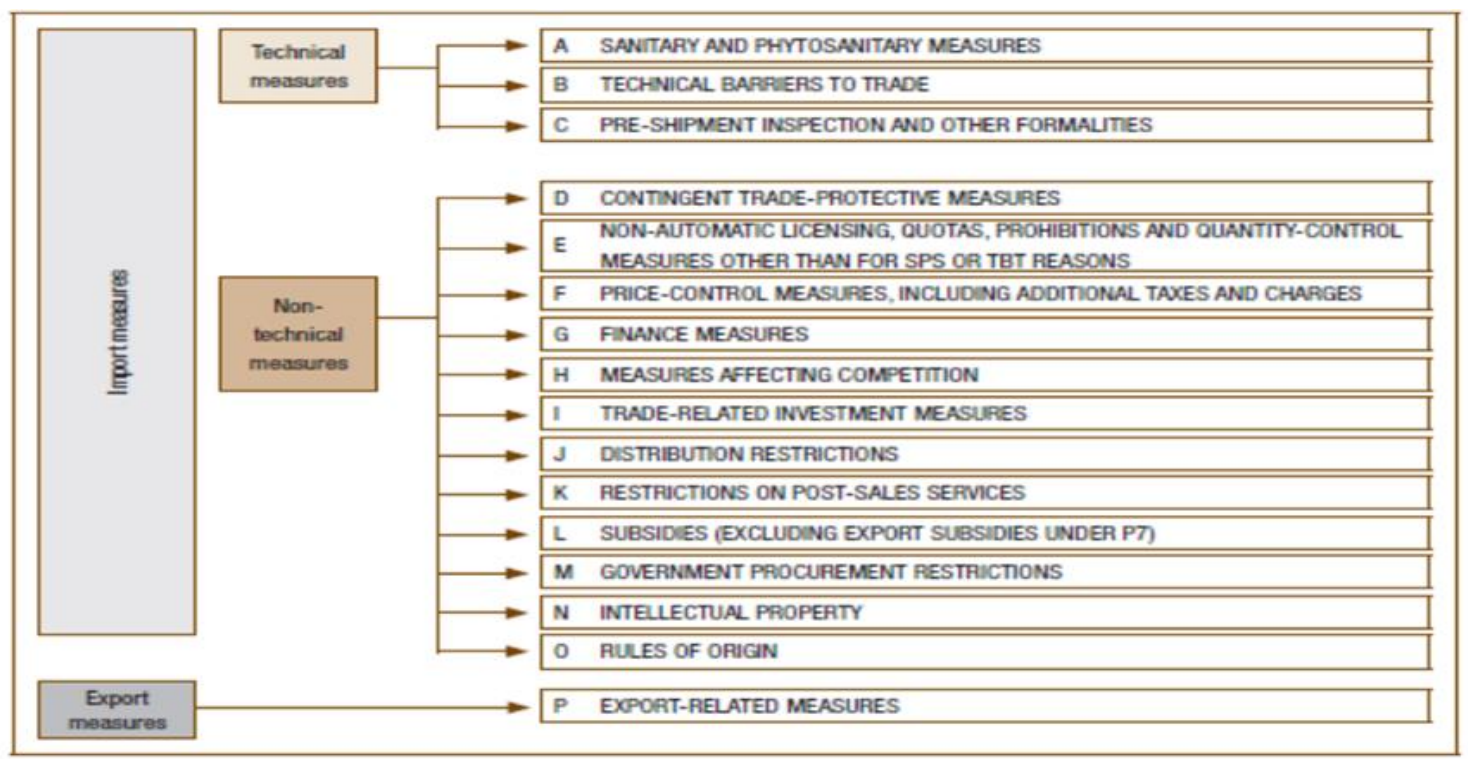

Sumber: UNCTAD, 2013

Gambar 2 Klasifikasi Baru non-tariff measures

Penggunaan jenis NTM seperti sanitary and phitosanitary (SPS) dan technical barriers to trade (TBT) memiliki dampak perdagangan yang paling banyak diakui dan diterapkan oleh negara-negara maju. Penerapan NTM lebih banyak diterapkan pada sektor pertanian daripada sektor manufaktur, baik di negara-negara high income, middle income maupun low income (ITC 2012). Sanitary and Phytosanitary (SPS) dan Technical Barriers to Trade (TBT) merupakan bagian dari technical measures. Kebijakan SPS termasuk peraturan dan pembatasan dengan tujuan untuk melindungi manusia, hewan atau tumbuhan hidup atau kesehatan. Sementara untuk TBT membahas mengenai semua peraturan teknis lainnya, standar dan prosedur penilaian kesesuaian.

Dalam prakteknya, kebijakan SPS dapat berbentuk: seluruh ketentuan, regulasi persyaratan dan prosedur terkait yang relevan, termasuk antara lain adalah kriteria produk akhir (end-product); metode proses dan produksi; prosedur pengujian, inspeksi, sertifikasi dan persetujuan; penanganan karantina; pengawasan terhadap metode statistik, prosedur sampling dan metode penilaian resiko yang relevan; serta persyaratan pengemasan dan pelabelan yang secara langsung terkait dengan keamanan makanan.

Bentuk kebijakan TBT berupa: regulasi teknis yang merupakan dokumen dalam menetapkan karakteristik produk atau yang terkait dengan proses dan cara produksinya, termasuk yang berlaku dalam ketentuan administratif. Hal ini juga dapat mencakup simbol, pengemasan, penandaan atau pelabelan seperti yang digunakan pada produk, proses atau cara produksi. Sedangkan prosedur penilaian kesesuaian adalah prosedur yang digunakan baik secara langsung maupun tidak langsung, untuk menentukan bahwa persyaratan relevan dalam peraturan teknis atau memenuhi standar, yang mencakup antara lain prosedur pengambilan sampel, pengujian dan inspeksi, evaluasi, dan sebagainya.

Bentuk penerapan hambatan perdagangan lainnya yang dipergunakan oleh negara-negara WTO adalah instrumen trade remedy berupa antidumping, subsidy dan tindakan safeguard. Langkah ini dinilai perlu dilakukan sebagai upaya strategi penyesuaian harga ekspor suatu barang sesuai dengan harga normal di 
dalam negeri, serta melakukan tindakan pengamanan untuk mencegah ancaman kerugian serius industri di dalam negeri (Barutu 2007).

Tindakan antidumping diberlakukan terhadap tindakan menjual suatu barang di pasar luar negeri dengan harga yang lebih rendah dari harga di pasar domestik, dimana selanjutnya pemerintah negara pengimpor dapat mengenakan bea masuk antidumping untuk menutupi kerugian sebagai dampak dari dumping tersebut. Sedangkan tindakan subsidi terjadi dimana produk dijual dengan harga murah karena mendapat subsidi oleh negara pengekspor. Pada prinsipnya tindakan subsidi dilarang jika hal itu dapat menimbulkan persaingan yang tidak sehat dan menimbulkan kerugian bagi negara pengimpor, sehingga negara pengimpor dapat memberlakukan tindakan imbalan (countervailing measures) terhadap produk yang dituduh mendapat subsidi dari negara pengekspor. Tindakan safeguard diberlakukan jika beredarnya barang impor yang masuk ke pasar domestik telah mengakibatkan terjadinya kerugian (injury) terhadap industri serupa di dalam negeri.

Kondisi saat ini di pasar dunia, industri kelapa sawit (CPO) harus bersaing dengan industri minyak nabati negara lain dan menghadapi isu negatif terhadap masalah kesehatan dan lingkungan sebagai bentuk hambatan perdagangan non-tariff yang efektif. Sementara di sisi lain, orentasi produksi minyak kelapa sawit nasional masih didominasi untuk pasar ekspor. Hambatan perdagangan yang diterapkan oleh negara-negara tujuan ekspor produk CPO mengharuskan Indonesia sebagai negara pengekspor memperhatikan persyaratan yang harus dipenuhi.

Oleh karena itu, berdasarkan latar belakang dan identifikasi yang telah diuraikan diatas maka memberikan ruang bagi peneliti untuk mengkaji lebih lanjut terkait permasalahan bagaimana daya saing dan pemberlakuan NTM terhadap komoditi CPO di negara-negara tujuan ekspor utamanya serta dampak pemberlakuan NTM terhadap kinerja ekspor komoditi CPO dan produk turunannya. Sehingga tujuan dari penelitian ini adalah menganalisis pengaruh NTM terhadap arus perdagangan ekspor komoditi CPO Indonesia ke negara-negara tujuan ekspor utamanya.

Berkenaan dengan tujuan tersebut, ada beberapa tinjauan pustaka/penelitian terdahulu yang menjadi dasar dalam melakukan penelitian ini, diantaranya penelitian yang dilakukan oleh Disdier et al. (2008) yang mengkaji dampak regulasi dari perdagangan sektor pertanian terkait dengan SPS dan TBT Agreements dengan menggunakan model gravity. Penelitian ini menggunakan inventory approach untuk mengukur perdagangan di sektor pertanian, dan melihat apakah SPS dan TBT measures mempengaruhi arus perdagangan serta bagaimana dampaknya bagi negara pengekspor. Hasilnya menyimpulkan bahwa SPS dan TBT measures secara signifikan mengurangi ekspor negara-negara berkembang ke negara-negara OECD tapi tidak mempengaruhi arus perdagangan antara negara anggota OECD.

Menurut penelitian yang dilakukan oleh Fassarella et al. (2011), mengkaji dampak dari sanitary dan technical measures terhadap ekspor daging unggas asal Brazil dengan menggunakan data bilateral antara Brazil dan negara mitra dagang utama periode 1996-2009. Hasil dari model gravity dengan estimasi fixed effect model menunjukkan bahwa dampak SPS dan TBT measures terhadap ekspor daging unggas Brazil adalah ambigu. Adanya peraturan teknis dan sanitasi yang berkaitan dengan pelabelan mungkin merangsang perdagangan terhadap produk daging unggas tersebut, sementara itu peraturan terkait penyesuaian muncul untuk mengurangi volume ekspor daging 
unggas Brazil. Hasil ini menunjukkan pentingnya dalam mempertimbangkan karakteristik yang berbeda serta isi peraturan untuk menganalisis dampak dari SPS dan TBT measures dalam perdagangan.

Penelitian lain yang terkait dengan NTM yaitu oleh Gomel et al. (2012) yang meneliti tentang pengaruh standar internasional pada arus ekspor Turki ke negara Uni Eropa. Penelitian ini bertujuan untuk menginvestigasi dampak standar internasional pada arus ekspor Turki ke negara UE. Turki telah secara positif bersama anggota perjanjian Custom Union dengan Uni Eropa dengan tanpa menjadi anggota UE dan perdagangan secara intensif dengan anggota inti persatuan tersebut. Penelitian ini menggunakan data sertifikasi ISO 9000 sebagai pendekatan untuk standar internasional. Penelitian ini mengadopsi model gravity dengan sampel dari negara-negara Uni Eropa 15 (EU15). Penelitian ini menggunakan panel gravity. Hasil dari penelitian ini menyarankan adopsi ISO 9000 di promosi ekspor Turki ke negara mitra dagang Eropa yang mungkin diindikasi dari signal kualitas produk yang tinggi.

Menurut penelitian yang dilakukan oleh Bratt (2014) yang mengkaji tentang dampak NTM terhadap arus perdagangan dapat berbeda antara masing-masing negara dengan menggunakan prosedur Heckman two-stage dari model gravity yang memasukkan variabel comparative advantage. Variabel tersebut terdiri dari factor endowments dari masing-masing negara mitra dagang dan menghasilkan country-spesific effects dari NTM. Hasilnya kemudian diubah ke dalam ad-valorem equivalents (AVEs), dan menjelaskan bahwa sejumlah NTM tidak menghambat perdagangan namun untuk sebagian besar kasus dampaknya secara keseluruhan terhadap perdagangan adalah negatif.

$$
\text { Adapun bagian kedua pada }
$$

penelitian ini akan disajikan mengenai metode penelitian. Kemudian bagian ketiga tentang hasil dan pembahasan dan bagian terakhir adalah simpulan dan saran serta daftar pustaka.

\section{METODE PENELITIAN}

Data yang digunakan dalam penelitian ini adalah data sekunder dari berbagai sumber antara lain WTO, World Bank (World Development Indicators), Trademap, CEPII, Fx Sauder, Kementerian Perdagangan RI, dan sumber lainnya. Data yang dikumpulkan tersebut merupakan data panel dengan time series tahunan 2003 - 2013 dan cross section dua puluh negara tujuan ekspor utama CPO Indonesia yaitu India, Uni Eropa, Cina, Malaysia, Singapura, Banglades, Pakistan, Mesir, Ukraina, Rusia, Myanmar, Afrika Selatan, Turki, Vietnam, Tanzania, Arab Saudi, Brazil, Jordania, Amerika Serikat dan Sri Lanka. Komoditi dalam penelitian ini didasarkan pada kode HS 1511 yaitu palm oil and its fractions. Metode analisis yang digunakan adalah analisis tingkat daya saing CPO, pemberlakuan NTM dan analisis data panel model gravity.

Periode waktu yang akan digunakan adalah tahun 2003-2013, karena CPO dinilai memiliki kinerja yang paling baik dan pangsa pasarnya terus meningkat dari sekitar $10 \%$ pada tahun 1970 -an menjadi sekitar $28 \%$ pada tahun 2000-an. NTM yang akan diestimasi pada penelitian ini dikhususkan pada Sanitary and Phytosanitary (SPS) dan Technical Barriers to Trade (TBT) untuk technical measures karena paling banyak digunakan oleh seluruh negara di dunia, serta instrumen trade remedy (antidumping, subsidy, dan safeguards) untuk non technical measures karena berdasarkan data di WTO bahwa antidumping juga paling banyak digunakan khususnya oleh negara-negara maju. Jenis dan sumber data untuk bahan penelitian secara ringkas disajikan dalam Tabel 2. 
Tabel 2. Jenis dan Sumber Data dalam Penelitian

\begin{tabular}{llll}
\hline No & Data & Sumber & Satuan \\
\hline 1 & Non-tariff measures & WTO & \\
2 & GDP & WDI & Juta US \$ \\
3 & Ekspor/ Impor & TRADE MAP & Juta US \$ \\
4 & Jarak & CEPII & Km \\
5 & Populasi & WDI & Jiwa \\
6 & Nilai Tukar & Fx Sauder & Rp/LCU \\
7 & IHK & WDI & \\
\hline
\end{tabular}

Analisis tingkat daya saing $\mathrm{CPO}$ Indonesia dengan negara tujuan ekspor utamanya menggunakan Revealed Comparative Advantage (RCA), kemudian mengevaluasi pemberlakuan NTM (incidence of non-tariff measures). Analisis ekonometrika dengan regresi data panel gravitasi digunakan untuk melihat dampak SPS, TBT dan trade remedy terhadap arus perdagangan ekspor CPO antara Indonesia dengan negara tujuan ekspor utamanya, menggunakan binary variable berupa dummy NTM bernilai 1 jika setidaknya ada satu NTM berlaku dan bernilai 0 jika sebaliknya.

Dalam gravity model sederhana, perdagangan antara negara $i$ dan negara $j$ bersifat proporsional terhadap ukuran ekonomi dan berbanding terbalik dengan jarak, yang menjadi proksi bagi biaya transportasi diantara kedua negara. Secara umum dapat digambarkan seperti berikut:

$$
\mathrm{X}_{\mathrm{ij}}=\mathrm{A} \frac{\mathrm{Y}_{\mathrm{i}} \mathrm{Y}_{\mathrm{j}}}{\mathrm{D}_{\mathrm{ij}}}
$$

Dimana $X_{\mathrm{ij}}$ adalah arus perdagangan ekspor antara negara $i$ dan negara $j . Y_{i}$ adalah GDP untuk negara $i$ dan $Y_{j}$ untuk negara $j . D_{i j}$ sebagai jarak geografis antara kedua negara.

Model yang digunakan berdasarkan asumsi bahwa ekspor negara i dari negara $\mathrm{j}$ tergantung pada variabel gravity seperti GDP dan jarak. Spesifikasi dasar dari persamaan gravity meliputi faktor-faktor dari negara pengimpor misalnya GDP riil dan juga jarak geografis sebagai proksi untuk biaya transportasi. Model gravity kemudian dikembangkan lagi oleh Wall
(1999) dengan mengestimasi menggunakan data panel, dimana model fixed effect dalam penelitiannya tersebut digunakan untuk mengestimasi dampak pembatasan impor terhadap ekspor dengan menambahkan indikator trade policy. Model gravity yang diperluas tersebut dituliskan sebagai berikut :

$\ln \mathrm{X}_{\mathrm{ijt}}=\alpha+\beta \ln Y_{i t}+\gamma \ln Y_{j t}-\delta \ln \mathrm{D}_{i j}+\lambda T_{j t}+\varepsilon_{i j t}$

Dimana $X_{\mathrm{ijt}}$ adalah ekspor antara negara $\mathrm{i}$ dan $\mathrm{j}$ pada periode tertentu; $Y_{i t}$ adalah GDP untuk negara i; $Y_{j t}$ adalah GDP untuk negara $j ; D_{i j}$ adalah jarak geografis antara negara i dan $\mathrm{j}$; dan $T_{j t}$ adalah Trade Policy Index (dapat berupa kebijakan perdagangan seperti NTM).

Dalam gravity model dari perdagangan bilateral, diperlukan pengujian asumsi pada data panel untuk mengetahui estimasi bias. Jika model yang terpilih berdasarkan uji Hausman adalah Random Effect Model (REM) maka estimasi dari model diasumsikan best linier unbiased estimator (BLUE) dan tidak perlu dilakukan pengujian terhadap tiga asumsi utama model BLUE (non-multicolinierity, homoskedasticity, dan non-autocorelation). Hal ini dikarenakan dua alasan, yaitu: (i) sifat data panel adalah bebas dari gejala multikolinieritas; dan (ii) REM adalah model generalized least square (GLS), dan estimasi dengan menggunakan GLS secara otomatis sudah terbebas dari gejala autokorelasi, bahkan terbebas dari gejala heteroskedastisitas yang disebabkan variansi sisaannya konstan (Gujarati 2004). 
Jika model yang terpilih adalah Fixed Effect Model (FEM) maka perlu dilakukan pengujian terhadap asumsi sisaan, sebagai berikut:

\section{a. Uji Heteroskedastisitas}

Asumsi pertama yang harus dipenuhi dalam persamaan regresi adalah bahwa taksiran parameter dalam model regresi bersifat BLUE maka varian $\left(\mathrm{u}_{\mathrm{i}}\right)$ harus sama dengan $\sigma^{2}$ (konstan), atau semua residual atau error memiliki varian yang sama. Kondisi itu disebut dengan homoskedastisitas. Apabila varian tidak konstan atau berubah-ubah disebut dengan heteroskedastisitas. Untuk mendeteksi adanya heteroskedastisitas dapat menggunakan metode Breusch-Pagan Test. Jika nilai probabilitas (Prob>chi2) lebih besar dari $\alpha$ (0.05) maka dapat disimpulkan bahwa tidak terjadi heteroskedastisitas. Hipotesis dari uji heteroskedastisitas:

$\mathrm{H}_{0}$ : Homoskedastisitas

$\mathrm{H}_{1}$ : Heteroskedastisitas

Hipotesis nol akan ditolak bila (Prob>chi2) $<\alpha$ atau nilai chi $2>$ nilai kritis t-tabel.

\section{b. Uji Autokorelasi}

Autokorelasi adalah korelasi yang terjadi antar observasi dalam satu peubah atau korelasi antara error masa yang lalu dengan error pada saat ini. Uji autokorelasi yang dilakukan tergantung pada jenis data dan sifat model yang digunakan. Autokorelasi dapat memengaruhi efisiensi dari penduganya. Untuk melakukan uji autokorelasi pada data panel dapat menggunakan Wooldridge test. Jika nilai probabilitas (Prob>F) lebih besar dari $\alpha$ (0.05) maka dapat disimpulkan bahwa tidak terjadi autokorelasi. Hipotesis dari uji autokorelasi:

$\mathrm{H}_{0}$ : tidak ada autokorelasi

$\mathrm{H}_{1}$ : ada autokorelasi

Hipotesis nol akan ditolak bila $($ Prob $>$ F $)<$ $\alpha$.

Pengujian parameter model bertujuan untuk mengetahui kelayakan model dan apakah koefisien yang diestimasi telah sesuai dengan teori atau hipotesis. Pengujian parameter tersebut adalah sebagai berikut:

\section{a. Uji-F}

Uji-F digunakan untuk melakukan uji hipotesis koefisien (slope) regresi atau parameter model secara menyeluruh/bersamaan. Kriteria pengujiannya adalah jika nilai nilai $F$ observasi $>\mathrm{F}$ tabel atau nilai probabilitas $F$-statistic $<$ taraf nyata $(\alpha)$, maka keputusan menolak $\mathrm{H}_{0}$ signifikan. Dengan menolak $\mathrm{H}_{0}$ berarti minimal ada satu peubah bebas yang berpengaruh nyata terhadap peubah tak bebas.

\section{b. Uji-t}

Setelah melakukan uji koefisien regresi secara keseluruhan, maka langkah selanjutnya adalah menguji koefisien regresi secara parsial menggunakan uji-t. Hipotesis pada uji-t adalah : $\mathrm{H}_{0}: \beta_{\mathrm{i}}=0 \mathrm{Vs}$ $\mathrm{H}_{1}: \beta_{\mathrm{i}} \neq 0$. Keputusan dalam pengujian ini dilakukan dengan membandingkan nilai t-hitung dengan t-tabel atau dengan melihat nilai probabilitas dari t-hitung. Jika nilai t-hitung $>\mathrm{t}$-tabel atau jika nilai probabilitas $\mathrm{t}<\alpha=0,05$ maka keputusan menolak $\mathrm{H}_{0}$ adalah signifikan. Kesimpulannya adalah peubah bebas secara parsial signifikan mempengaruhi peubah tak bebas.

\section{c. Koefisien Determinasi $\left(\mathbf{R}^{2}\right)$}

Koefisien determinasi (Goodness of Fit) merupakan suatu ukuran yang penting dalam regresi, karena dapat menginformasikan baik atau tidaknya model regresi hasil estimasi. Nilai $R^{2}$ mencerminkan seberapa besar variasi dari peubah bebas $Y$ dapat diterangkan oleh peubah tak bebas $X$. Jika $\mathrm{R}^{2}=0$, maka variasi dari $Y$ tidak dapat diterangkan oleh $X$ sama sekali, namun jika $\mathrm{R}^{2}=1$ maka variasi dari $Y$ secara keseluruhan dapat diterangkan oleh $X$. Semakin tinggi nilai koefisien determinasi maka model akan semakin baik. 
Oleh karena itu, spesifikasi model yang digunakan dalam penelitian ini merujuk pada model gravity yang dibuat oleh Disdier et al. (2008) dan Fassarella et al. (2011). Adapun model yang digunakan dalam penelitian ini adalah:

Model 1:

$$
\begin{aligned}
{\ln \_E X_{i j t}=\alpha_{0}+} & \alpha_{1}{\ln \_G D P_{j t}}+\alpha_{2} \ln \_ \text {distance }_{i j t} \\
& +\alpha_{3} \ln \_ \text {population } \\
& +\alpha_{4} \ln _{-} \text {realer }_{i j t}+\alpha_{5} \text { ntm }_{i j t} \\
& +\varepsilon_{i j t}
\end{aligned}
$$

Model 2:

$$
\begin{aligned}
{\ln \_E X_{i j t}=\alpha_{0}+} & \alpha_{1}{\ln \_G D P_{j t}}+\alpha_{2} \ln \_d i s t a n c e_{i j t} \\
& +\alpha_{3} \ln \_ \text {population } \\
& +\alpha_{4} \ln \_ \text {realer } \\
& +\alpha_{5} \text { dum_s }_{i j t} \\
& +\alpha_{6} \text { dum_tbt }_{i j t} \\
& +\alpha_{7} \text { dum_tr } r_{i j t}+\varepsilon_{i j t}
\end{aligned}
$$

Keterangan:

- $\ln \_E X_{\mathrm{ijt}}=$ Ekspor negara $\mathrm{i}$ ke negara $\mathrm{j}$ pada tahun $t$ (juta \$US), dalam log natural $(\ln )$;

- $\ln \_G D P P_{j t}=$ GDP riil negara pengimpor $j$ pada tahun $\mathrm{t}$ (juta \$US), dalam log natural $(\ln )$;

- In_distance ${ }_{\mathrm{ijt}}=$ Jarak ekonomi antara negara eksportir i dan importir j, dalam $\log$ natural (ln). Penghitungan jarak ekonomi adalah sebagai berikut:

$$
\operatorname{Jarak}_{i j t}=\left(\frac{\text { Jarak geografis }}{P D B_{j} / \Sigma P D B_{\text {seluruh negara yang dianalisis }}}\right)_{t}
$$

- In_population ${ }_{\mathrm{jt}}=$ Populasi negara pengimpor $\mathrm{j}$ pada tahun $\mathrm{t}$ (jiwa), dalam log natural $(\ln )$;

- In_realer ${ }_{i j t}=$ Nilai tukar riil negara pengekspor i terhadap negara pengimpor j pada tahun (Rp/LCU), dalam log natural (ln). Penghitungan nilai tukar riil adalah sebagai berikut:

Kurs $_{i j t}=\left(\frac{I H K \text { negara } j}{I H K \text { negara }}\right)_{t} \times\left(\frac{\text { Nilai tukar nominal negara } i / \$}{\text { Nilai tukar nominal negara } j / \$}\right)_{t}$

- $\mathrm{ntm}_{\mathrm{ijt}}=$ Variabel dummy untuk NTM yang berupa SPS, TBT dan trade remedy negara pengimpor $\mathrm{j}$ pada negara pengekspor i pada tahun t. Bernilai 1 jika terdapat salah satu NTM , dan bernilai 0 jika sebaliknya;

- dum_sps ${ }_{\mathrm{ijt}}=$ Variabel dummy untuk NTM yang berupa kebijakan SPS negara pengimpor $\mathrm{j}$ pada negara pengekspor $\mathrm{i}$ pada tahun t. Bernilai 1 jika terdapat NTM jenis SPS, dan bernilai 0 jika sebaliknya;

- dum_tbt $\mathrm{ijt}_{\mathrm{jt}}=$ Variabel dummy untuk NTM yang berupa kebijakan TBT negara pengimpor $\mathrm{j}$ pada negara pengekspor $\mathrm{i}$ pada tahun t. Bernilai 1 jika terdapat NTM jenis TBT, dan bernilai 0 jika sebaliknya;

- dum_tr $\operatorname{trjt}_{\text {t }}=$ Variabel dummy untuk NTM yang berupa kebijakan trade remedy negara pengimpor $j$ pada negara pengekspor i pada tahun t. Bernilai 1 jika terdapat NTM jenis trade remedy, dan bernilai 0 jika sebaliknya;

- $\mathrm{i}=$ Indonesia (negara pengekspor)

- $\mathrm{j}=$ Dua puluh negara tujuan ekspor/negara pengimpor utama

- $\alpha_{0}=$ Konstanta / intersep

- $\alpha_{1}, \alpha_{2}, \alpha_{3}, \alpha_{4}, \alpha_{5}, \alpha_{6}, \alpha_{7}, \alpha_{8}=$ Parameter yang diestimasi

- $\varepsilon_{i j t}=$ Error term

Keputusan untuk memilih model yang digunakan dalam analisis data panel didasarkan pada uji Hausman. Uji Hausman dilakukan untuk memilih apakah model yang digunakan Fixed Effect atau Random Effect (Firdaus 2011). Digunakan model Fixed Effect apabila statistik uji yang dihasilkan tolak $\mathrm{H}_{0}$ dan menggunakan Random Effect apabila tidak tolak $\mathrm{H}_{0}$.

\section{HASIL DAN PEMBAHASAN}

\section{a. Analisis Tingkat Daya Saing CPO}

Nilai RCA menunjukkan keunggulan komparatif atau daya saing ekspor dalam suatu komoditas dari suatu negara terhadap dunia. RCA dapat didefinisikan bahwa jika pangsa komoditi CPO Indonesia ke negara tujuan ekspor utamanya di dalam total ekspor suatu negara lebih besar dibandingkan pangsa pasar ekspor komoditi CPO di dalam total ekspor komoditi dunia, diharapkan negara tersebut memiliki keunggulan komparatif dalam ekspor komoditi CPO tersebut. 
Sehingga secara matematis penelitian ini menggunakan rumus RCA dengan modifikasi sebagai berikut:

$$
\mathrm{RCA}=\frac{X_{p q / X_{p}}}{W_{p q} / W_{p}}
$$

Dimana $X_{\mathrm{pq}}$ merupakan nilai ekspor komoditas q dari Indonesia ke negara $\mathrm{p} ; \mathrm{X}_{\mathrm{p}}$ merupakan nilai ekspor total (produk $\mathrm{q}$ dan lainnya) dari Indonesia ke negara $\mathrm{p} ; \mathrm{W}_{\mathrm{pq}}$ merupakan nilai ekspor komoditas q dunia ke negara $\mathrm{p}$; dan $\mathrm{W}_{\mathrm{p}}$ merupakan nilai ekspor total dunia ke negara p. Jika nilai RCA suatu negara untuk komoditas tertentu adalah lebih besar dari 1 (satu), maka negara bersangkutan memiliki keunggulan komparatif di atas rata-rata dunia untuk komoditas tersebut, dan sebaliknya. Semakin besar nilai RCA, semakin tinggi pula tingkat keunggulan komparatifnya.

Tabel 3 Hasil Perhitungan Nilai RCA Komoditi CPO Indonesia ke Negara Tujuan Ekspor Utamanya

\begin{tabular}{clcccccc}
\hline \multirow{2}{*}{ No } & Negara Tujuan & \multicolumn{7}{c}{ Hasil Nilai RCA } & Rata-rata \\
\cline { 2 - 6 } & Ekspor & 2009 & 2010 & 2011 & 2012 & 2013 & $2010-2013$ \\
\hline 1 & India & 34.17 & 34.09 & 27.04 & 23.98 & 21.98 & 26.77 \\
2 & Uni Eropa & 120.55 & 114.47 & 85.00 & 91.86 & 103.92 & 98.81 \\
3 & Cina & 33.75 & 35.25 & 24.17 & 33.57 & 31.55 & 31.13 \\
4 & Malaysia & 18.45 & 19.63 & 14.11 & 13.51 & 13.00 & 15.06 \\
5 & Singapura & 39.04 & 33.63 & 20.37 & 22.87 & 29.79 & 26.67 \\
6 & Banglades & 20.67 & 20.88 & 19.63 & 20.55 & 19.43 & 20.12 \\
7 & Pakistan & 5.33 & 2.67 & 5.87 & 10.63 & 13.67 & 8.21 \\
8 & Mesir & 45.54 & 46.88 & 43.57 & 71.51 & 54.60 & 54.14 \\
9 & Ukraina & 116.44 & 136.70 & 208.02 & 292.56 & 253.62 & 222.72 \\
10 & Rusia & 27.84 & 113.64 & 141.37 & 146.16 & 150.95 & 138.03 \\
11 & Myanmar & - & 11.30 & 10.39 & 8.15 & 16.15 & 11.50 \\
12 & Afrika Selatan & 51.09 & 57.92 & 28.28 & 28.72 & 48.56 & 40.87 \\
13 & Turki & 32.07 & 26.59 & 30.00 & 81.98 & 70.64 & 52.31 \\
14 & Vietnam & 17.95 & 14.64 & 11.10 & 10.97 & 9.67 & 11.60 \\
15 & Tanzania & 44.29 & 33.31 & 35.43 & 35.98 & 42.19 & 36.73 \\
16 & Arab Saudi & 51.22 & 7.08 & 11.16 & 35.31 & 55.42 & 27.24 \\
17 & Brazil & 96.79 & 121.41 & 94.12 & 96.08 & 116.21 & 106.95 \\
18 & Jordania & 57.37 & 40.15 & 11.75 & 39.46 & 32.01 & 30.85 \\
19 & Amerika Serikat & 13.85 & 5.47 & 3.53 & 5.50 & 35.74 & 12.56 \\
20 & Sri Lanka & 3.98 & 5.91 & 9.65 & 8.28 & 14.27 & 9.53 \\
\hline
\end{tabular}

Sumber: TRADE MAP, diolah 2014

Pada Tabel 3 diperoleh hasil estimasi nilai RCA komoditi CPO Indonesia ke negara tujuan ekspor utamanya, yang seluruhnya menunjukkan nilai lebih dari satu. Artinya komoditi CPO Indonesia memiliki daya saing yang baik dalam pasar dunia. Daya saing yang baik ini merupakan nilai lebih Indonesia dalam memajukan perekonomiannya, karena komoditi CPO ini termasuk ke dalam kelompok komoditi utama Indonesia menurut versi pemerintah yang mendapatkan perhatian lebih dalam pengembangan ekspornya bagi Indonesia.
Negara yang memiliki nilai rata-rata RCA tertinggi yang lebih dari dan hampir mendekati 100 yaitu Ukraina $(222,72)$, Rusia $(138,03)$, Brazil $(106,95)$ dan Uni Eropa $(98,81)$ menunjukkan bahwa komoditi CPO memiliki tingkat daya saing yang sangat besar dibandingkan dengan dunia. Sedangkan rata-rata RCA terendah tapi nilainya masih lebih dari 1 (satu) yaitu pada negara Srilanka $(9,53)$ dan Pakistan $(8,21)$.

Jika dilihat nilai RCA antara tahun 2010-2013 di beberapa tujuan ekspor utamanya seperti India, Malaysia, 
Bangladesh dan Vietnam mengalami penurunan. Namun, nilai RCA juga terlihat berfluktuatif antara tahun 2010-2013. Hal itu terjadi di negara Uni Eropa, Cina, Singapura, Mesir, Ukraina, Myanmar, Africa Selatan, Turki, Brazil, Jordania, Amerika Serikat dan Srilanka. Terjadinya penurunan dan fluktuasinya nilai RCA tersebut diindikasikan adanya NTM yang diterapkan oleh negara pengimpor terhadap komoditi CPO Indonesia, tetapi tidak terlepas juga dari kondisi masing-masing perekonomian negara pengimpornya.

Nilai RCA juga akan semakin besar karena adanya kesepakatan khusus antara Indonesia dengan negara-negara tujuan ekspor utamanya tersebut mengenai pemenuhan kebutuhan terhadap komoditi ini di pasar masing-masing negara tujuan ekspor utamanya. Misalnya saja Uni Eropa, karena adanya kesepakatan khusus antara Indonesia dengan negara-negara Uni Eropa mengenai pemenuhan kebutuhan akan komoditi CPO ini di pasar Uni Eropa, sehingga meskipun dalam kondisi krisis sekalipun pada tahun 2008-2009, namun aliran perdagangan Indonesia dan Uni Eropa terhadap komoditi ini cenderung tidak terlalu berfluktuatif, bahkan trennya terlihat terus meningkat.

Komoditi CPO merupakan primary goods yang dibutuhkan bagi negara-negara mitra dagang dalam industri-industrinya. Hal ini sesuai dengan penelitian Oktaviani (2008) yang menunjukkan komoditi yang tergolong primary goods memiliki daya saing tinggi dengan nilai RCA yang lebih dari satu. Tentu saja Indonesia sebagai salah satu penghasil hasil bumi terbesar dunia menjadi salah satu pemasok utama dalam memenuhi kebutuhan mereka terhadap komoditi CPO. Keadaan ini menjadikan Indonesia memiliki daya saing yang tinggi di pasar dunia.

\section{Non-Tariff Measures pada Komoditi CPO Indonesia}

Pada bagian ini akan dilakukan analisis pemberlakuan NTM terhadap komoditi CPO Indonesia pada negara tujuan ekspor utamanya dengan pendekatan dalam menghitung jumlah pemberlakuan NTM (incidence of non-tariff measures). Incidence of non-tariff measures menyajikan sebaran penggunaan NTM baik berdasarkan negara tujuan ekspor, komoditas, dan jenis NTM.

Perdagangan komoditi ekspor CPO Indonesia menghadapi berbagai hambatan di beberapa negara tujuan ekspor khususnya NTM yang berpotensi akan merugikan kepentingan perdagangan Indonesia. NTM tersebut berupa sanitary and phytosanitary (SPS), technical barriers to trade (TBT) dan trade remedy (antidumping, subsidy, dan safeguards) yang disajikan pada Tabel 4 dengan jumlah pemberlakuan masing-masing sebanyak 34 kebijakan untuk SPS, 102 kebijakan untuk TBT, serta 4 kebijakan untuk trade remedy.

Pada Tabel 4 dapat diketahui bahwa dari 20 (dua puluh) negara tujuan ekspor utama komoditi CPO Indonesia, terdapat 10 (sepuluh) negara tujuan ekspor utama yang mengenakan kebijakan-kebijakan NTM khususnya SPS, TBT dan trade remedy. Sisanya sebanyak 10 (sepuluh) negara tujuan ekspor utamanya tidak mengenakan kebijakan NTM, negara-negara tersebut adalah India, Singapura, Banglades, Mesir, Ukraina, Rusia, Myanmar, Tanzania, Jordania dan Srilanka. 
Tabel 4 Non-Tariff Measures yang Diberlakukan pada Komoditi CPO Indonesia di Negara-negara Tujuan Ekspor Utamanya tahun 2003-2013

\begin{tabular}{|c|c|c|c|c|c|c|c|}
\hline \multirow{2}{*}{ No. } & \multirow{2}{*}{$\begin{array}{c}\text { Negara } \\
\text { Tujuan Ekspor }\end{array}$} & \multirow{2}{*}{ SPS } & \multirow{2}{*}{ TBT } & \multicolumn{3}{|c|}{ Trade Remedy } & \multirow{2}{*}{ Jumlah } \\
\hline & & & & Dumping & Subsidy & Safeguards & \\
\hline 1 & India & - & - & - & - & - & 0 \\
\hline 2 & Uni Eropa & 11 & 8 & 2 & 1 & - & 22 \\
\hline 3 & Cina & 6 & 7 & - & - & - & 13 \\
\hline 4 & Malaysia & - & 2 & - & - & - & 2 \\
\hline 5 & Singapura & - & - & - & - & - & 0 \\
\hline 6 & Bangladesh & - & - & - & - & - & 0 \\
\hline 7 & Pakistan & - & 26 & - & - & - & 26 \\
\hline 8 & Mesir & - & - & - & - & - & 0 \\
\hline 9 & Ukraina & - & - & - & - & - & 0 \\
\hline 10 & Rusia & - & - & - & - & - & 0 \\
\hline 11 & Myanmar & - & - & - & - & - & 0 \\
\hline 12 & Afrika Selatan & 1 & 1 & - & - & - & 2 \\
\hline 13 & Turki & - & 2 & - & - & - & 2 \\
\hline 14 & Vietnam & - & - & - & - & 1 & 1 \\
\hline 15 & Tanzania & - & - & - & - & - & 0 \\
\hline 16 & Arab Saudi & 6 & 20 & - & - & - & 26 \\
\hline 17 & Brazil & 2 & 3 & - & - & - & 5 \\
\hline 18 & Jordania & - & - & - & - & - & 0 \\
\hline 19 & Amerika Serikat & 8 & 33 & - & - & - & 41 \\
\hline 20 & Sri Lanka & - & - & - & - & - & 0 \\
\hline & Jumlah & 34 & 102 & 2 & 1 & 1 & 140 \\
\hline
\end{tabular}

Sumber: WTO dan Direktorat Pengamanan Perdagangan (Kemendag RI), diolah 2014

India tidak memberlakukan baik SPS, TBT dan trade remedy, namun pada tahun 2002 pernah mengenakan tindakan safeguard terhadap produk CPO Indonesia dan kasusnya sudah dihentikan pada tanggal 24 Januari 2003. Singapura dan Banglades juga tidak memberlakukan baik SPS, TBT dan trade remedy, meskipun nilai ekspor CPO Indonesia ke kedua negara tersebut mengalami penurunan tapi bukan karena adanya penerapan NTM. Hal ini dikarenakan kedua negara tersebut memperoleh CPO tidak hanya dari Indonesia saja tapi juga impor dari Malaysia, sehingga impor dari Indonesia berkurang. Sementara itu untuk Mesir, Ukraina, Rusia, Myanmar dan Srilanka juga tidak memberlakukan baik SPS, TBT dan trade remedy, hal ini pula yang menjadi alasan negara tujuan ekspor CPO Indonesia ditujukan ke negara-negara tersebut yang dibuktikan dengan meningkatnya pertumbuhan ekspor CPO pada tahun 2012-2013.

Kebijakan SPS yang banyak diberlakukan antara lain terkait dengan labeling dan packaging yang berhubungan langsung dengan food safety requirements, food additives, dan terkait certification. Kebijakan TBT yang banyak diberlakukan antara lain berkaitan dengan food standard, labeling (terkait informasi nutrisi), comformity assessment, dan quality requirements. Sementara itu pada penerapan NTM jenis trade remedy yang banyak diberlakukan adalah dumping.

Negara tujuan ekspor yang paling banyak memberlakukan NTM untuk komoditi CPO Indonesia adalah Amerika Serikat sebanyak 41 kebijakan, dengan SPS sebanyak 8 kebijakan dan TBT sebanyak 33 kebijakan. Kemudian negara yang memberlakukan NTM terbanyak selanjutnya yaitu Pakistan, Saudi Arabia dan Uni Eropa dengan masing-masing sebanyak 26 kebijakan, 26 kebijakan dan 22 kebijakan. Pakistan menerapkan NTM berupa TBT sebanyak 26 kebijakan. Saudi Arabia memberlakukan NTM dengan SPS sebanyak 6 kebijakan dan TBT sebanyak 20 kebijakan. Sedangkan Uni Eropa menerapkan NTM dengan SPS sebanyak 
11 kebijakan, TBT sebanyak 8 kebijakan dan trade remedy sebanyak 3 kebijakan (berupa 2 kebijakan antidumping dan 1 kebijakan subsidy).

\section{Binary Variable}

Untuk mengevaluasi dampak NTM pada level produk, variabel dummy banyak digunakan dalam penelitian (Demaria et al. 2011). Variabel dummy untuk NTM yang berupa SPS, TBT dan trade remedy negara pengimpor $\mathrm{j}$ pada negara pengekspor $\mathrm{i}$ pada tahun t. Dummy NTM bernilai 1 jika terdapat setidaknya satu NTM yang diterapkan dan bernilai 0 jika tidak ada NTM yang diterapkan.

Hal ini dimungkinkan untuk menggunakan binary variable atau discrete variable yang sering menjadi karakter NTM dalam pendekatan gravitasi. Oleh karena itu, memasukkan NTM secara eksplisit ke dalam model akan lebih berguna, bahkan jika hanya sebagai variabel dummy, daripada tidak mengikutsertakan NTM sebagai alasan untuk errors yang tidak dapat dijelaskan dalam estimasi model (Bellanawithana dan Wijerathne 2009).

\section{b. Analisis Data Panel dengan Model Gravity}

Analisis dampak SPS, TBT dan trade remedy ini dimulai dengan membahas mengenai pengujian model gravity. Hal ini dilakukan agar memperoleh model yang layak dan estimasi yang bersifat BLUE (Best Linier Unbiased Estimator), kemudian menganalisis faktor-faktor yang mempengaruhi ekspor CPO Indonesia. Terakhir menganalisis dampak SPS, TBT dan trade remedy sesuai dengan model yang telah diperoleh.

Dalam penelitian ini, untuk memperoleh model yang cocok maka dilakukan uji kelayakan dan kecocokan model (goodness of fit). Untuk memperoleh estimasi yang bersifat BLUE maka dilakukan juga pengujian asumsi dasar. Hasil estimasi yang menggunakan gravity model tersebut dilakukan dengan program software Stata 12.

\section{Hasil Estimasi Model Data Panel}

Analisis pengaruh NTM terhadap arus perdagangan ekspor komoditi $\mathrm{CPO}$ Indonesia ke negara tujuan ekspor utama menggunakan panel data statis pada gravity model dari tahun 2003-2013. Hasil uji chow menunjukkan bahwa Fixed Effect Model (FEM) lebih baik daripada Pooled Least Square (PLS), hal ini dilihat dari nilai statistik uji chow sebesar 9,13 (Prob $>\mathrm{F}=0,000$ ). Uji Breusch Pagan LM memberikan hasil bahwa Random Effect Model (REM) lebih baik dari PLS dengan nilai statistik sebesar 49,89 (Prob $>$ chibar2=0,000). Berdasarkan kedua pengujian tersebut, maka dilakukan uji Hausman untuk menentukan model FE atau RE yang akan digunakan pada penelitian ini. Hasil uji Hausman menunjukkan bahwa FEM lebih baik dari REM dengan nilai statistik sebesar 50,51 (Prob $>$ Chi Square $=0,000$ ) sehingga model yang digunakan adalah Fixed Effect Model.

\section{Uji Kelayakan dan Kecocokan Model (Goodness of fit) \\ Uji kelayakan model menunjukkan} bahwa nilai probability ( $F$-Statistic) pada model yang digunakan adalah 0,000 sehingga dapat disimpulkan bahwa minimal terdapat satu variabel bebas yang mempengaruhi variabel tidak bebas. Uji kecocokan model (goodness of fit) ditunjukkan pada nilai koefisien determinasi $\left(\mathrm{R}^{2}\right)$. Model menunjukkan nilai $R^{2}$ sebesar 0,40 yang berarti variasi variabel bebas berupa GDP riil, jarak ekonomi, populasi, real exchange rate, dan dummy NTM mampu menjelaskan variabel tak bebas (nilai ekspor) sebesar $40 \%$, sedangkan sisanya dijelaskan oleh faktor-faktor lainnya diluar model. 


\section{Uji Asumsi Dasar}

Uji asumsi dasar dilakukan untuk memperoleh estimasi yang bersifat BLUE (Best Linier Unbiased Estimator). Uji asumsi dasar ini meliputi uji multikolinearitas, heteroskedastisitas, dan autokorelasi. Uji multikolinearitas yang dilakukan pada model mengindikasikan adanya multikolinearitas yang ditunjukkan dengan adanya nilai korelasi antar variabel bebas dan tidak bebas bernilai lebih dari 0,75 . Hal ini dapat dilihat pada Tabel 5, sehingga dengan demikian dapat disimpulkan bahwa antar variabel yang diteliti terjadi multikolinearitas.

Tabel 5 Uji Multikolinearitas

\begin{tabular}{r|rrr} 
& ln_exp t & ln_gdp & In_dis e l. \\
\hline In_export & 1.0000 & & \\
ln_gdp & 0.2702 & 1.0000 & \\
ln_distance & 0.1033 & 0.9455 & 1.0000 \\
ln_populat n & 0.3716 & 0.6920 & 0.7108 \\
ln_realer & 0.0253 & 0.4623 & 0.4630 \\
dum_sps & 0.1025 & 0.4127 & 0.4168 \\
dum_tbt & -0.0586 & 0.4375 & 0.4495 \\
dum_tr & 0.1208 & 0.1447 & 0.1229
\end{tabular}

Uji heteroskedastisitas dilihat dari hasil Modified Wald Test sebagaimana Tabel 6. Dari tabel tersebut, dapat dilihat bahwa model mengalami heteroskedastisitas yang ditunjukkan dengan nilai wald test lebih kecil dari $\alpha$ $(0,05)$.

Tabel 6 Uji Heteroskedastisitas

\begin{tabular}{ll}
\hline Wald Test & Chi Square \\
\hline 0.0000 & 8041.15 \\
\hline
\end{tabular}

Kemudian pada uji autokorelasi dapat dilihat dari hasil Wooldridge test seperti pada Tabel 7. Menurut tabel di bawah ini, model mengandung autokorelasi yang ditunjukkan dengan nilai F Stat lebih kecil dari $\alpha(0,05)$. Untuk mengatasi masalah pada model, maka digunakan model panel data dengan General Least Square (GLS) untuk mengatasi pelanggaran asumsi tersebut.

Tabel 7 Uji Autokorelasi

\begin{tabular}{cc}
\hline F Stat & Probability \\
\hline 0.0000 & 30.473 \\
\hline
\end{tabular}

\section{Faktor yang Mempengaruhi Arus Perdagangan Ekspor CPO Indonesia}

Berdasarkan hasil pengujian Model 1 dan Model 2 diperoleh informasi bahwa arus perdagangan ekspor komoditi $\mathrm{CPO}$ Indonesia dipengaruhi oleh GDP negara pengimpor, jarak ekonomi, populasi, nilai tukar riil, dan dummy NTM (kebijakan non tarif). Model 1 memberikan informasi bahwa NTM mempengaruhi arus perdagangan ekspor CPO Indonesia. Variabel dummy NTM digunakan sebagai variabel yang dapat menangkap pengaruh dari arus perdagangan ekspor komoditi CPO Indonesia. Berdasarkan hasil estimasi pada Model 1 yang dilakukan dalam penelitian ini, dummy NTM memberikan pengaruh yang tidak signifikan terhadap arus perdagangan ekspor Indonesia pada komoditi CPO. Tetapi nilai koefisien pada dummy NTM bernilai $-0,06$, tanda negatif pada dummy NTM mengindikasikan adanya hambatan non tarif pada arus perdagangan ekspor CPO Indonesia yang berpengaruh pada turunnya nilai ekspor. 
Tabel 8 Hasil estimasi dampak non-tariff measures (koefisien parameter dengan GLS) periode 2003-2013

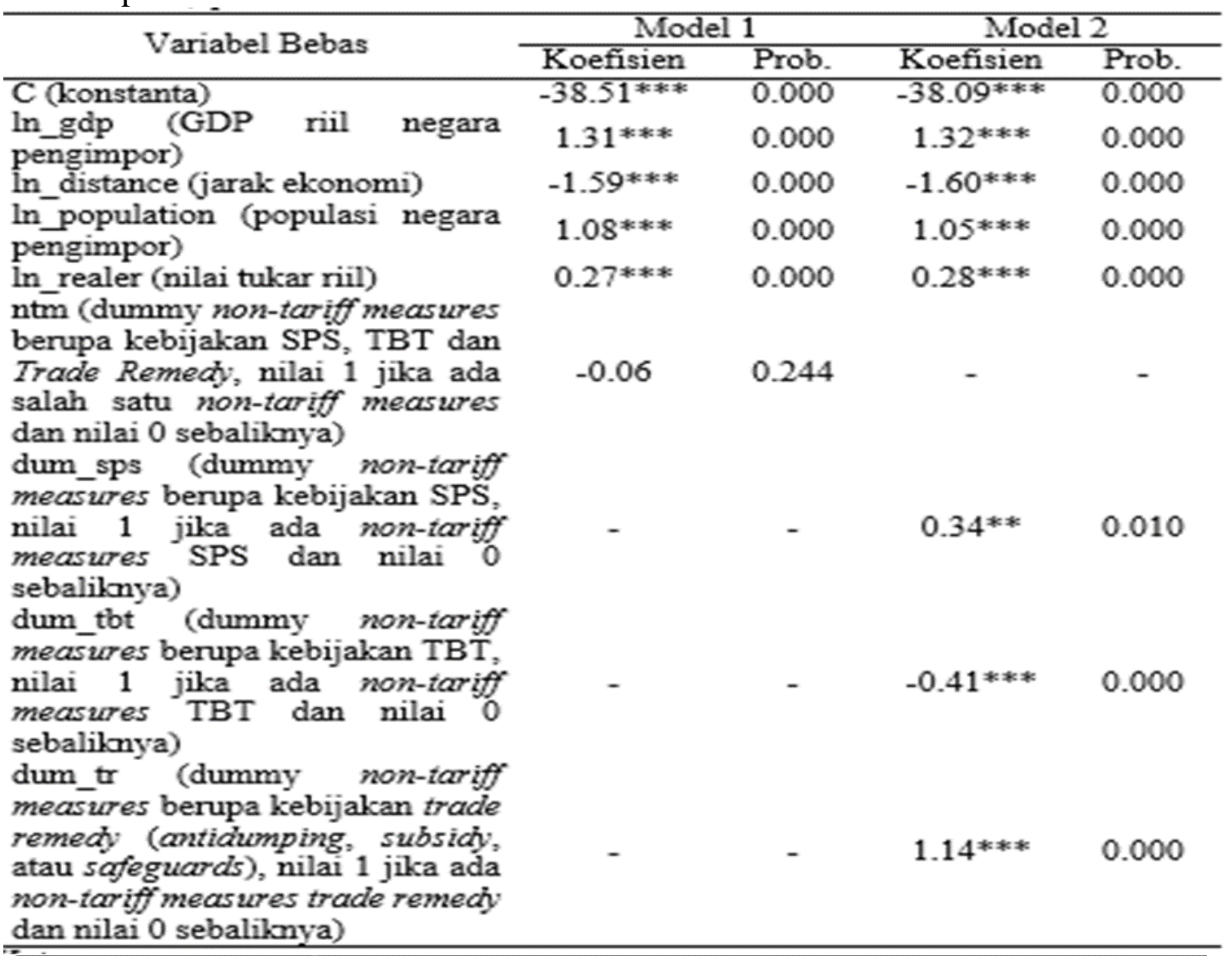

Keterangan:

1) Variabel tak bebas $=\ln$ _export (ekspor CPO Indonesia ke negara mitra dagang utama)

2) Tingkat signifikansi pada taraf nyata: $* * *=1 \%$ dan $* *=5 \%$

Namun jika didisagregasi menjadi perdagangan ekspor Indonesia pada tiga berdasarkan jenis NTM (Model 2) komoditi CPO.

berupa kebijakan SPS, TBT dan trade remedy maka informasi yang diperoleh adalah kebijakan TBT yang berkaitan dengan regulasi teknis dan standar berdampak negatif, sedangkan kebijakan SPS yang berkaitan dengan persyaratan prosedur tentang kesehatan dan keselamatan berdampak positif terhadap arus perdagangan ekspor komoditi CPO. Begitu pula dengan kebijakan trade remedy (antidumping, subsidy, safeguard) berdampak positif terhadap arus perdagangan ekspor komoditi CPO Indonesia seperti terlihat pada Tabel 8 . Ketiga dummy NTM tersebut memberikan pengaruh yang signifikan terhadap arus

\section{GDP Riil Negara Pengimpor}

GDP riil negara pengimpor memiliki hubungan yang positif terhadap arus perdagangan ekspor CPO Indonesia. Pengaruhnya positif dengan significant level sebesar $1 \%$ dan dengan nilai koefisien sebesar 1,32. Dari hasil tersebut dapat disimpulkan bahwa jika terjadi peningkatan GDP riil negara pengimpor sebesar $1 \%$ maka pengaruhnya akan meningkatkan ekspor CPO Indonesia sebesar 1,32\%, ceteris paribus. Peningkatan pendapatan yang terjadi pada negara pengimpor akan meningkatkan permintaan ekspor CPO Indonesia. Hal ini 
menyimpulkan bahwa kenaikan yang terjadi pada pendapatan suatu negara akan berdampak positif terhadap kenaikan permintaan akan barang komoditas ekspor. Hasil penelitian ini sejalan dengan temuan yang dilakukan oleh Bellanawithana dan Wijerathne (2009).

\section{Jarak Ekonomi (Distance)}

Biaya ekspor (biaya transportasi) dalam penelitian ini diukur dengan nilai jarak ekonomi suatu negara. Jarak ekonomi merupakan salah satu syarat yang cukup penting pada gravity model dan besarnya jarak ekonomi akan mempengaruhi arus perdagangan ekspor secara negatif. Hasil estimasi yang diperoleh model menunjukkan bahwa variabel distance berpengaruh signifikan terhadap ekspor dengan taraf nyata $1 \%$ dan besaran nilai koefisiennya yaitu 1,60. Koefisien tersebut bernilai negatif sehingga sesuai dengan teori ataupun hipotesis pada penelitian ini.

Nilai koefisien dengan tanda negatif tersebut mengindikasikan bahwa apabila jarak dengan negara tujuan ekspor lebih jauh $1 \%$ maka akan terjadi penurunan ekspor CPO sebesar $1,60 \%$, ceteris paribus. Hal ini sesuai dengan teori gravity dimana jarak mempengaruhi interaksi antara dua objek. Semakin jauh jarak negara tujuan dengan Indonesia maka semakin besar biaya transportasi untuk perdagangan $\mathrm{CPO}$ dari Indonesia. Hasil ini sejalan dengan penelitian yang dilakukan oleh Bellanawithana dan Wijerathne (2009), yang menjelaskan bahwa koefisien jarak yang bernilai negatif mengindikasikan semakin besar jarak antar negara akan meningkatkan biaya transportasi sehingga dapat menurunkan perdagangan.

\section{Populasi Negara Pengimpor}

Nilai koefisien variabel populasi negara pengimpor sebesar 1,05. Hal ini mengindikasikan jika populasi negara pengimpor meningkat $1 \%$ maka nilai ekspor CPO akan meningkat sebesar $1,05 \%$, ceteris paribus. Kondisi ini sesuai dengan hipotesis penelitian yang menjelaskan bahwa populasi negara pengimpor berpengaruh positif pada ekspor CPO Indonesia.

Populasi negara pengimpor berpengaruh signifikan pada taraf nyata $1 \%$ terhadap aliran perdagangan ekspor $\mathrm{CPO}$ Indonesia. Adanya pertambahan populasi pada negara pengimpor akan meningkatkan jumlah CPO yang dapat diekspor karena adanya pertambahan konsumsi di negara tersebut, ceteris paribus. Konsumsi yang meningkat di negara pengimpor akan meningkatkan jumlah produk CPO yang diimpor. Dengan demikian, Indonesia sebagai negara pengekspor dapat meningkatkan jumlah ekspornya di negara pengimpor tersebut.

Besarnya populasi pada suatu negara menunjukkan potensi pasar yang besar bagi negara pengekspor. Populasi menjadi suatu indikasi untuk meningkatkan jumlah ekspor, sehingga dapat berpengaruh positif. Negara-negara dengan populasi yang besar dapat menjadi sebagai suatu potensi pasar bagi Indonesia untuk dapat lebih dikembangkan, misalnya seperti India, Uni Eropa dan Cina yang merupakan negara tujuan ekspor terbesar untuk komoditi CPO Indonesia serta memiliki populasi jumlah penduduk yang terus bertambah setiap tahunnya. Hal ini sejalan dengan penelitian yang dilakukan oleh Zarzoso dan Lehmann (2003) yang menyatakan bahwa koefisien positif pada variabel populasi negara pengimpor menunjukkan ukuran suatu negara berhubungan langsung dengan perdagangan, yang berarti bigger countries memiliki kapasitas yang lebih besar untuk menyerap impor daripada smaller countries.

\section{Nilai Tukar Riil (Real Exchange Rate)}

Hasil estimasi yang diperoleh model menunjukkan bahwa variabel realer (nilai tukar riil) berpengaruh signifikan terhadap 
ekspor dengan taraf nyata $1 \%$ dan besaran nilai koefisiennya yaitu 0,28 . Hal tersebut berarti jika terjadi peningkatan nilai tukar riil sebesar $1 \%$ maka akan meningkatkan arus perdagangan ekspor sebesar 0,28\%, ceteris paribus. Nilai tukar rupiah terhadap mata uang negara pengimpor $\mathrm{CPO}$ yang diteliti memberikan pengaruh yang nyata terhadap ekspor CPO Indonesia.

Nilai tukar riil meningkat atau mata uang negara pengekspor terdepresiasi maka akan mengakibatkan harga produk di negara pengekspor menjadi lebih murah sehingga mendorong permintaan produk dari negara lain. Arus perdagangan ekspor akan meningkat karena permintaan produk CPO meningkat. Stabilitas nilai tukar riil mata uang Indonesia terhadap mata uang negara lain merupakan syarat penting bagi perdagangan komoditi CPO. Hal ini sesuai dengan penelitian yang dilakukan oleh Zarzoso dan Lehmann (2003) yang menyatakan bahwa terjadinya depresiasi mata uang di negara pengekspor akan dapat menaikkan ekspor.

\section{Kebijakan non tarif (non-tariff measures)}

Efek untuk NTM tidak dapat dipastikan karena dapat bermakna ambigu (dapat memiliki efek negatif dan efek positif). NTM dapat menghambat perdagangan karena meningkatnya biaya kepatuhan (conformity assessment reqirements) bagi produsen, tetapi juga dapat meningkatkan permintaan karena mengurangi biaya informasi bagi konsumen (Fugazza 2013).

Hasil estimasi Model 1 menunjukkan bahwa hipotesis awal yang menyatakan adanya pengaruh negatif NTM terhadap arus perdagangan ekspor CPO telah terbukti tapi tidak berpengaruh secara signifikan. Penggunaan NTM untuk melakukan proteksi perdagangan suatu negara mempengaruhi arus perdagangan ekspor CPO Indonesia walaupun tidak signifikan.
Hasil estimasi Model 2 menunjukkan bahwa NTM mempengaruhi arus perdagangan ekspor CPO Indonesia secara signifikan dengan memisahkan variabel jenis NTM menjadi tiga yaitu SPS, TBT dan trade remedy. Namun, menariknya hasil estimasi pada Model 2 memperlihatkan bahwa hanya TBT yang menyatakan adanya pengaruh negatif terhadap arus perdagangan ekspor CPO Indonesia, sedangkan SPS dan trade remedy menyatakan adanya pengaruh positif. Pentingnya NTM bukan hanya dari ada atau tidaknya tetapi juga bagaimana dampak nyatanya dalam perdagangan internasional.

\section{Dampak Non-Tariff Measures terhadap Ekspor CPO Indonesia ke Negara Tujuan Utama}

Efek dari NTM sering menjadi ambigu dan sensitif secara politis. Di satu sisi, peraturan atau regulasi yang sering diperlukan untuk mengurangi market failures, tapi di sisi lain peraturan domestik mungkin dikenakan hanya untuk menghambat impor pesaing asing (Beghin 2008). Analisis teoritis tidak memberikan kesimpulan yang pasti tentang efek keseluruhan terkait dengan regulasi, selanjutnya dibutuhkan bukti lain dan kemudian beralih ke analisis empiris. Mengevaluasi dampak NTM tersebut tidak sederhana dan membutuhkan estimasi yang tidak mudah (Dee dan Ferrantino 2005).

Pengaruh NTM pada kebijakan SPS nyata pada level signifikansi 5\% namun koefisiennya bernilai positif yaitu 0,34 , sedangkan pada kebijakan TBT nyata pada level signifikansi $1 \%$ dengan nilai koefisien sebesar -0,41, serta pada kebijakan trade remedy juga nyata pada level signifikansi $1 \%$ namun koefisiennya bernilai positif yaitu 1,41 . Oleh karena itu, kebijakan yang lebih dominan 
mempengaruhi arus perdagangan ekspor komoditi CPO adalah kebijakan TBT.

\section{Kebijakan SPS (Sanitary and Phytosanitary Measures)}

NTM berupa kebijakan SPS yang diberlakukan di negara tujuan ekspor (negara pengimpor) komoditi CPO Indonesia meliputi labeling dan packaging yang berkaitan langsung dengan food safety requirements, food additives, serta terkait certification. Berdasarkan hasil estimasi memperlihatkan bahwa peningkatan cakupan NTM dalam kebijakan SPS sebesar $1 \%$ akan meningkatkan arus perdagangan ekspor sebesar $0,34 \%$, ceteris paribus. Dapat juga diartikan bahwa penggunaan kebijakan SPS tidak selalu menghambat perdagangan, tetapi ternyata dapat meningkatkan arus perdagangan ekspor. Indikator yang digunakan untuk mengukur penggunaan kebijakan SPS adalah dummy variable (binary variable) dari penggunaan tiga jenis NTM tersebut.

Berdasarkan hasil estimasi tersebut terdapat efek ganda SPS dan TBT di bidang pertanian yaitu dapat tidak berdampak pada perdagangan atau bahkan memfasilitasi perdagangan dengan membawa informasi dari produk impor, dengan asumsi bahwa eksportir dapat mengatasi persyaratan teknis terkait dan dokumen; tetapi SPS atau TBT juga bisa menjadi hambatan dalam perdagangan ketika negara-negara tidak dapat memenuhi standar (Disdier, Fontagne dan Mimouni 2008). Hal ini memperkuat kesimpulan bahwa tidak semua SPS dan TBT di bidang pertanian adalah perangkat proteksionis.

Pengaruh positif kebijakan SPS terhadap arus perdagangan ekspor berlawanan dengan hipotesis yang ditentukan pada awal penelitian. Namun, hasil pengujian ini sejalan dengan penelitian Fasarella, Souza dan Burnquist (2011) yang menyatakan bahwa kebijakan
SPS (berupa labeling dan pelarangan/karantina) meningkatkan arus perdagangan ekspor Brazil pada produk daging unggas. Fenomena ini juga terjadi pada perdagangan ekspor komoditi CPO Indonesia. Peningkatan kebijakan SPS yang didalamnya merupakan kebijakan terkait dengan persyaratan prosedur yang bertujuan untuk melindungi kesehatan dan kehidupan makhluk hidup termasuk prosedur pengujian, sertifikasi, karantina, labeling dan packaging yang berhubungan langsung dengan food safety, dapat meningkatkan arus perdagangan ekspor.

Terkait dengan pengaruh kebijakan SPS terhadap arus perdagangan ekspor CPO Indonesia, maka dapat dijelaskan bahwa kebijakan SPS merupakan kebijakan yang mengangkat aspek kesehatan serta keselamatan dan saat ini telah menjadi concern tidak hanya bagi negara maju tapi juga negara berkembang. Ketika negara mitra dagang (negara pengimpor) Indonesia menerapkan kebijakan dalam bentuk SPS measures yang meliputi sertifikasi, pengujian, labeling serta packaging yang berkaitan dengan kesehatan dan keamanan makanan maka eksportir Indonesia terdorong untuk menghasilkan produk yang sesuai dengan persyaratan dan prosedur yang relevan. Hal ini juga sesuai dengan penelitian Bellanawithana dan Wijerathne (2009) terkait perdagangan pada sektor pertanian di Asia Selatan yang menjelaskan bahwa NTM akan lebih ketat $1 \%$ di negara pengimpor dan akan meningkatkan nilai perdagangan ekspor pertanian sebesar 5,3\%. Alasannya karena dengan NTM yang ketat akan meningkatkan kualitas produk dan meskipun dapat meningkatkan harga, namun akhirnya akan membantu eksportir untuk mendapatkan keunggulan kompetitif.

Semakin besarnya cakupan produk yang sudah sesuai dengan persyaratan SPS negara pengimpor maka produk ekspor asal Indonesia semakin diterima di pasar 
negara lain. Meskipun kebijakan seperti ini dapat meningkatkan harga, namun konsumen akan lebih percaya dengan kualitas produk ekspor Indonesia. Selain itu negara pengimpor bukan merupakan penghasil dari komoditi CPO. CPO juga tidak dikonsumsi secara langsung sebagaimana misalnya produk ikan atau daging dan harus mengalami proses pengolahan lagi (intermediate good). CPO mempunyai rantai pengolahan yang panjang sebelum menjadi ingredients produk jadi, hal ini yang menjadikan CPO sebagai bahan dasar yang dibutuhkan untuk berbagai macam produk manufaktur (end user) khususnya di banyak negara maju dan negara berkembang. Oleh karena itu, kebijakan SPS tidak dapat menghalangi ekspor CPO dari Indonesia sebagai produsen sekaligus eksportir terbesar di dunia.

Jika dilihat pada pemberlakuan NTM khususnya kebijakan SPS yang diterapkan oleh negara tujuan ekspor komoditi CPO Indonesia, mengindikasikan bahwa jumlah kebijakan SPS lebih sedikit daripada kebijakan TBT. Negara yang paling banyak menerapkan kebijakan SPS tersebut adalah Uni Eropa sebanyak 11 kebijakan dan Amerika Serikat sebanyak 8 kebijakan. Sementara negara lainnya yaitu Cina sebanyak 6 kebijakan, Saudi Arabia sebanyak 6 kebijakan, Brazil sebanyak 2 kebijakan dan Afrika Selatan sebanyak 1 kebijakan. Uni Eropa menjelang tahun 2015 telah menyatakan bahwa hanya akan menerima CPO yang memiliki sertifikasi sustainable. Respons positif yang telah diperoleh dari Uni Eropa terhadap diplomasi dagang Indonesia untuk mengonvergensikan sertifikat ISPO (Indonesian Sustainable Palm Oil) dengan RSPO (Roundtable on Sustainable Palm Oil).

Amerika Serikat meskipun menerapkan kebijakan SPS tapi dapat dilihat pada nilai ekspornya yang cenderung meningkat trennya, bahkan pada tahun 2013 nilai ekspor CPO Indonesia ke Amerika Serikat melonjak tajam. Demikian pula terjadi peningkatan nilai ekspor CPO Indonesia ke Brazil setiap tahunnya. Negara lainnya yang menerapkan kebijakan SPS yaitu Cina, dapat dijelaskan bahwa terjadi fluktuasi pada nilai ekspor CPO Indonesia ke Cina tetapi selama periode 2009-2013 trennya cenderung positif. Namun pada tahun 2013 nilainya menurun karena pasar CPO di Cina diprediksi mengecil seiring dengan perlambatan pertumbuhan ekonominya. Negara selanjutnya yang menerapkan kebijakan SPS adalah Saudi Arabia dan Afrika Selatan, dapat dijelaskan juga bahwa nilai ekspor CPO Indonesia ke pasar Saudi Arabia dan Afrika Selatan mengalami fluktuasi. Tetapi selama periode 2009-2013 trennya cenderung positif.

Contoh kasus yang terkait dengan kebijakan SPS adalah AQSIQ (General Administration of Quality Supervision, Inspection and Quarantine) Republik Rakyat Tiongkok (RRT/Cina) telah menemukan produk makanan asal Indonesia (refined palm oil) yang tidak memenuhi syarat yang diekspor ke Cina pada bulan September 2011. Produk tersebut telah dimusnahkan karena mengandung acid sebesar 0.25-0.29 $\mathrm{mgKOH} / \mathrm{g}$ dan jumlah peroxide sebesar $6.49 \mathrm{mmol} / \mathrm{kg}$ sesuai ketentuan yang berlaku. Diharapkan pihak/instansi terkait dapat mengambil langkah-langkah efektif dan memperketat pengawasan sehingga dapat menjamin keamanan mutu makanan yang diekspor ke RRT. Kemudian pada tanggal 22 Mei 2012, AQSIQ juga menerbitkan 2012 (No.80) Decree on Requirements for Transport Containers for Importing Bulky Vegetable Oils. Regulasi tersebut mengatur tentang persyaratan bahan yang digunakan untuk membuat wadah pengiriman minyak nabati, daftar bahan yang dilarang dimuat dan dikapalkan, dan larangan untuk 
menggunakan wadah yang telah digunakan untuk dua kali pengiriman. Regulasi tersebut mulai berlaku pada tanggal 1 Januari 2013 (Direktorat Pengamanan Perdagangan 2012).

Penerapan kebijakan SPS terutama pada labeling dan packaging yang berkaitan langsung dengan food safety, food additives, serta certification hendaknya tidak dianggap sebagai hambatan perdagangan saja namun perlu dijadikan motivasi oleh setiap negara terutama Indonesia untuk menghasilkan produk yang berkualitas dan berdaya saing tinggi. Oleh karena itu, dapat disimpulkan dari beberapa alasan tersebut bahwa kebijakan SPS yang diterapkan di negara-negara tujuan ekspor utamanya (negara pengimpor) tidak menghambat dan dapat meningkatkan arus perdagangan ekspor CPO Indonesia.

\section{Kebijakan TBT (Technical Barriers to} Trade Measures)

NTM berupa kebijakan TBT yang diberlakukan di negara tujuan ekspor (negara pengimpor) komoditi CPO Indonesia meliputi food standard, labeling (terkait informasi nutrisi), comformity assessment, dan quality requirements. Berdasarkan hasil estimasi menjelaskan bahwa peningkatan cakupan NTM dalam kebijakan TBT sebesar $1 \%$ akan menurunkan arus perdagangan ekspor sebesar $0,41 \%$, ceteris paribus. Indikator yang digunakan untuk mengukur penggunaan kebijakan TBT adalah dummy variable (binary variable).

Pengaruh negatif kebijakan TBT terhadap arus perdagangan ekspor sesuai dengan hipotesis yang ditentukan pada awal penelitian. Penelitian oleh Moenius (2006) menjelaskan bahwa standar khusus (kebijakan TBT) dari negara pengimpor secara negatif mempengaruhi arus perdagangan pada sektor pertanian. Hasil pengujian ini juga sejalan dengan penelitian Fasarella, Souza dan Burnquist
(2011) yang menyatakan bahwa kebijakan TBT (berupa technical measures yang khususnya terkait dengan conformity assessment procedur) akan menurunkan arus perdagangan ekspor Brazil pada produk daging unggas. Fenomena ini juga terjadi pada perdagangan ekspor komoditi CPO Indonesia. Peningkatan kebijakan TBT yang didalamnya merupakan kebijakan terkait dengan regulasi teknis, dan prosedur penilaian kesesuaian (conformity assessment procedur) dengan peraturan teknis dan standar, termasuk langkah-langkah yang tercakup dalam perjanjian SPS, dapat menurunkan arus perdagangan ekspor.

Hasil penelitian yang dilakukan oleh Chen et al. (2006) juga menjelaskan bahwa conformity assessment procedure secara signifikan menghambat perdagangan dan prosedur pengujian merupakan hal yang memberatkan bagi perusahaan di sektor pertanian. Penilaian kesesuaian (conformity assessment) mengacu pada pengujian, inspeksi dan sertifikasi, serta pernyataan kesesuaian dari pemasok. Hal tersebut diperlukan untuk mencapai tujuan penting dari suatu kebijakan, salah satunya yaitu perlindungan kesehatan dan keamanan konsumen. Pengujian, inspeksi dan sertifikasi sesuai dengan regulasi TBT akan memerlukan biaya, karena biaya ini diperlukan untuk memastikan kepatuhan terhadap standar yang telah ditetapkan.

Jika dilihat pada pemberlakuan NTM khususnya kebijakan TBT yang diterapkan oleh negara tujuan ekspor komoditi CPO Indonesia, mengindikasikan bahwa jumlah kebijakan TBT lebih banyak diterapkan daripada kebijakan SPS dan trade remedy. Negara yang paling banyak menerapkan kebijakan TBT tersebut adalah Amerika Serikat sebanyak 33 kebijakan, Pakistan sebanyak 26 kebijakan dan Arab Saudi sebanyak 20 kebijakan. Sementara negara lainnya yaitu Uni Eropa sebanyak 8 kebijakan, Cina sebanyak 7 kebijakan, Brazil sebanyak 3 kebijakan, Malaysia dan 
Turki masing-masing sebanyak 2 kebijakan serta Afrika Selatan sebanyak 1 kebijakan.

Contoh kasus dari Cina melalui AQSIQ Shi Jian 2012 (No. 229) mengeluarkan notifikasi mengenai Further Enhancing Supervision of Vegetable Oil Import Inspection pada tanggal $14 \mathrm{Mei}$ 2012. Dalam tersebut dinyatakan bahwa importir bertanggung jawab terhadap kualitas dan keamanan minyak nabati (vegetable oils) yang diimpor. Secara spesifik, importir harus memberikan jaminan bahwa minyak nabati yang diimpor telah memenuhi persyaratan di dalam undang-undang standar Pemerintah Cina dengan memiliki dokumen yang relevan yang menyatakan bahwa produk yang diimpor telah memenuhi standar Cina, membuat catatan impor dan penjualan yang dapat dilacak, serta mempekerjakan pegawai yang mengenal baik regulasi mengenai kualitas dan keamanan Cina. Pemerintah Cina telah memberlakukan standar yang lebih ketat terhadap impor produk CPO Indonesia mulai Januari 2013 terutama terkait dengan acid value (Direktorat Pengamanan Perdagangan 2012).

Oleh karena itu, dapat disimpulkan dari beberapa alasan tersebut bahwa kebijakan TBT yang diterapkan di negara-negara tujuan ekspor utamanya (negara pengimpor) tersebut menghambat dan dapat menurunkan arus perdagangan ekspor CPO Indonesia.

\section{Kebijakan Trade Remedy (Antidumping,} Subsidy, Safeguard)

NTM berupa kebijakan trade remedy yang diberlakukan di negara tujuan ekspor (negara pengimpor) komoditi CPO Indonesia meliputi antidumping, subsidy, dan safeguard. Peningkatan cakupan NTM dalam kebijakan trade remedy sebesar $1 \%$ akan meningkatkan arus perdagangan ekspor sebesar $1,14 \%$, ceteris paribus. Penggunaan kebijakan trade remedy ternyata tidak secara langsung menghambat perdagangan dan dapat meningkatkan arus perdagangan ekspor. Indikator yang digunakan untuk mengukur penggunaan kebijakan trade remedy adalah dummy variable (binary variable).

Pengaruh positif kebijakan trade remedy terhadap arus perdagangan ekspor berlawanan dengan hipotesis yang ditentukan pada awal penelitian. Bukti pengenaan trade remedy harus berbasis unfair trade, namun kenyataannya banyak yang tidak berbasis scientific evidence melainkan alasan politis karena proteksi. Kecenderungan penggunaan non-tariff measures pada trade remedy terjadi pada spesifik produk (produk hilir), sedangkan CPO merupakan produk hulu. Untuk produk hilir dari komoditi CPO misalnya berupa fatty alcohol dan biodiesel, sehingga tidak secara langsung mempengaruhi (menurunkan) ekspor CPO ke negara mitra dagangnya.

Contoh kasus terkait adalah kasus dumping dan subsidy atas produk biodiesel asal Indonesia ke Uni Eropa. European Biodiesel Bord (EBB) mendapat tekanan kuat dari produsen utama biofuel di Uni Eropa (Jerman, Perancis dan Italia) untuk mencermati lonjakkan impor produk biofuel dari Indonesia dan Argentina yang sangat mengganggu pangsa pasar mereka dan telah mendominasi pasar impor biofuel Uni Eropa. Selain itu pada tahun 2011 terjadi lonjakan impor biodiesel ke Belanda dari 41958,4 ton pada tahun 2010 menjadi 155 465,6 ton pada tahun 2011 atau meningkat sebesar $270,52 \%$, market share volume Indonesia ke Belanda naik dari $2,68 \%$ menjadi $9,34 \%$ pada tahun 2011. Besar kemungkinan lonjakan impor dan market share Indonesia ke Belanda menjadi pemicu inisiasi rencana tuduhan dumping. Setelah dilakukan penyelidikan maka pada awal bulan Desember 2013 Komisi Eropa memutuskan bahwa pelaku usaha Indonesia telah melakukan praktek dumping. Oleh karena itu dikenakan Bea 
Masuk Anti Dumping (BMAD) dengan kisaran $8,8 \%$ hingga $20,5 \%(76,94 € \mathrm{~s} / \mathrm{d}$ $178,85 €$ ) per ton (Direktorat Pengamanan Perdagangan 2013).

Alasan lain yang mendukung bahwa trade remedy tidak selalu menghambat perdagangan karena negara pengimpor yang mengenakan tuduhan dumping atau subsidy atau safeguard tidak serta merta menghentikan kebutuhannya atas komoditi tersebut. Karena pada dasarnya mereka akan selalu membutuhkan CPO Indonesia untuk kebutuhannya, baik kebutuhan untuk industrinya maupun terkait food security dan energy security (tren penggunaan energi terbarukan). Selain itu dampaknya terhadap perdagangan tidak dihentikan karena akhir dari pengenaan tuduhan trade remedy tersebut yaitu berupa pengenaan bea masuk yang sifatnya hanya sementara (berkisar antara 4 sampai 5 tahun), kemudian setelah tahun pengenaan tersebut telah selesai maka dapat tetap melanjutkan perdagangannya. (Oke Nurwan 31 Oktober 2014, komunikasi langsung).

\section{SIMPULAN DAN SARAN}

\section{Simpulan}

Berdasarkan uraian diatas maka dapat disimpulkan bahwa:

1. Kinerja perdagangan ekspor Indonesia diukur menggunakan nilai RCA untuk mengidentifikasi daya saing CPO Indonesia, dan hasilnya menunjukkan semuanya lebih dari satu. Artinya komoditi CPO Indonesia memiliki daya saing yang baik di pasar dunia dan merupakan salah satu komoditi unggulan ekspor Indonesia.

2. GDP negara pengimpor, jarak ekonomi, populasi negara pengimpor, dan nilai tukar riil merupakan faktor yang dapat meningkatkan arus perdagangan ekspor CPO Indonesia. Jenis NTM yang digunakan yaitu SPS, TBT dan trade remedy (antidumping, subsidy, safeguard). Negara pengimpor utama yang paling banyak mengenakan NTM adalah Amerika Serikat, dan kebijakan TBT lebih banyak diterapkan oleh negara pengimpor utamanya.

3. Secara keseluruhan NTM dari negara-negara tujuan ekspor utamanya menghambat arus perdagangan ekspor komoditi CPO Indonesia, tetapi pengaruhnya tidak nyata. Namun jika NTM didisagregasi berdasarkan jenisnya berupa SPS, TBT dan trade remedy, hasilnya menunjukkan bahwa pengaruh NTM pada kebijakan SPS signifikan pada taraf nyata 5\% namun koefisiennya bernilai positif yaitu 0,34 , sedangkan pada kebijakan TBT signifikan pada taraf nyata $1 \%$ dengan nilai koefisien sebesar -0,41, serta pada kebijakan trade remedy juga signifikan pada taraf nyata $1 \%$ namun koefisiennya bernilai positif yaitu 1,41 . Oleh karena itu, kebijakan yang lebih dominan menghambat arus perdagangan ekspor komoditi CPO Indonesia adalah kebijakan TBT.

\section{Saran}

Beberapa hal yang dapat disarankan berdasarkan uraian pada penelitian ini adalah:

1. Penambahan variabel dalam perhitungan dari proksi pengaruh NTM dan dapat dilakukan pada komoditi lainnya untuk melihat pengaruhnya dari sisi komoditi/produk. Untuk penelitian selanjutnya dapat dikembangkan juga model analisis yang mempertimbangkan model Computable General Equilibrium untuk melihat dampak ekonomi secara makro maupun mikro.

2. Penelitian ini dapat dikaji lebih luas lagi dengan melakukan analisis dampak NTM terhadap negara selain Indonesia, atau bahkan membandingkan penerapan NTM dari negara maju dengan non-tariff measures dari negara 
berkembang. Penelitian lebih lanjut juga dapat menambah jenis NTM lainnya (selain dari SPS, TBT dan trade remedy) dan dapat dilakukan dengan metode pendekatan lain yang tersedia, sehingga dapat diperoleh perbandingan dari metode-metode yang digunakan sebelumnya.

\section{DAFTAR PUSTAKA}

Badan Pusat Statistik [BPS]. 2013. Statistik Kelapa Sawit Indonesia. Publikasi BPS.

Jakarta.http://www.bps.go.id/hasil _publikasi/stat_kelapa_sawit_2012 /index3.php?pub=Statistik\%20Kel apa\%20sawit\%20Indonesia\%2020 12. [diakses 25 Mei 2014]

2014.

Pertumbuhan Ekonomi Indonesia. Berita Resmi Statistik BPS No. 16/02/Th. XVII, 5 Februari 2014. Jakarta.

Barutu C. 2007. Ketentuan Antidumping, Subsidi dan Tindakan Pengamanan (Safeguard) dalam GATT dan WTO. Bandung: PT. Citra Aditya Bakti.

Bellanawithana A, Wijerathne B, Weerahewa J. 2009. Impacts of Non-Tariff Measures (NTMs) on Agricultural Exports: A Gravity Modeling Approach. Asia-Pacific Trade Economists Conference. University of Peradeniya, Srilanka: ESCAP.

Bratt M. 2014. Estimating the Bilateral Impact of Non-Tariff Measures (NTMs). Working Paper Series 14-01-1. Geneva, Switzerland.

Demaria F, Rau M, Schlueter S. 2011. NTMs and gravity-type models: state of the art and analysis of the literature. NTM Impact Working Paper 11/01. European Commission $7^{\text {th }}$ Framework Programme.
Disdier AC, Lionel F, Mondher M. 2008. The Impact of Regulations on Agricultural Trade: Evidence from SPS and TBT Agreements. American Journal of Agricultural Economics 90(2):336-350.

Fassarella LM, Mauricio JPS, Heloisa LB. 2011. Impact of Sanitary and Technical Measures on Brazilian Exports of Poultry Meat. Selected Paper prepared for presentation at the Agricultural \& Applied Economics Association's 2011 AAEA \& NAREA Joint Annual Meeting July 24-26, 2011. Pittsburgh, Pennsylvania.

Firdaus M. 2011. Aplikasi Ekonometrika untuk Data Panel dan Time Series. Bogor : IPB Press.

Fugazza M. 2013. The Economics behind Non-Tariff Measures: Theoretical Insights and Empirical Evidence. Policy Issues in International Trade and Commodities Study Series No.57. UNCTAD: Geneva.

Gomel F, Nihal T, Tune D. 2012. The Effect of International Standards on Turkish Export Flows to the EU Countries. Journal. Department of Economics, Yildiz Technical University, Turkey. http://www.etsg.org/ETSG2013/Pa pers/228.pdf. [diakses 2 Mei 2014] Gujarati D. 2004. Basic Econometrics, $4^{\text {th }}$ Edition. The McGraw-Hill Companies.

Hai TC. 2004. Selling the green palm oil advantage?. Oil Palm Industry Economic Journal, Vol. 4 (1), pp. 22-31.

[ITC] International Trade Centre. 2012. Non-Tariff Measures: A Key Issue in Evolving Trade Policy. International Trade Forum Magazine October 01, 2012. http://www.tradeforum.org/article/ $\underline{\text { Non-tariff-measures-A-key-issue-i }}$ 
n-evolving-trade-policy/. [diakses 18 Mei 2014]

Krugman, Obstfeld. 2003. International Economics Theory and Policy. Massachusetts : An imprint of Addison Wesley Longman, Inc.

Kementerian Perdagangan RI. 2012. Warta Hambatan Perdagangan. Edisi 001/2012. Direktorat Pengamanan Perdagangan, Kementerian Perdagangan.

Moenius J. 2006. The Good, the Bad and the Ambiguous: Standards and Trade in Agriculture Products. Paper presented at IATRC Summer Symposium "Food Regulation and Trade: Institutional Framework, Concepts of Analysis and Empirical Evidence”. Bonn. Germany, 28-30 May.

Oktaviani R. 2008. Consultancy and Training Services to Develop Quantitative Analytical Tools and Framework for Assessing Investment and Trade Competitiveness. Department of Economics FEM IPB in collaboration with BAPPENAS and Partnership Governance Reform.

Salvatore D. 1997. International Economics. New Jersey: Prentice Hall- Gale.

TRADEMAP. 2014. List of importing markets for a product exported by Indonesia, Product: 1511 Palm oil \& its fraction. http://www.trademap.org/Country SelProductCountry_TS.aspx [terhubung berkala].

[UNCTAD] United Nations Conference on Trade Development. 2013.
Non-Tariff Measures to Trade: Economic and Policy Issues for Developing Countries. Switzerland. Geneva.

[USDA] United States Departement of Agriculture. 2013. Indonesia: Long-Term Prospects for U.S. Agricultural Exports. International Agricultural Trade Reports. http://www.fas.usda.gov/data/indo nesia-long-term-prospects-us-agric ultural-exports. [diakses 17 Februari 2014]

Van Gelder JW. 2004. Greasy palms: European buyers of Indonesian palm oil. http://www.foe.co.uk/resource/rep orts/greasy_palms_buyers.pdf. [diakses 10 September 2013]

Wall H. 1999. Using the Gravity Model to Estimate the Costs of Protection. Federal Reserve Bank of St. Louis Review. Jan:33-40.

[WTO] World Trade Organization. 2013. Non-Tariff Measures Data. http://i-tip.wto.org/goods/Forms/T ableView.aspx?mode=modify\&act ion=search. [terhubung berkala].

World Trade Report. 2012. The Trade Effects of Non-Tariff Measures and Service

Measures.http://www.wto.org/engl ish/res_e/booksp_e/anrep_e/world trade_report12_e.pdf. [diakses 2 Juni 2014]

Zarzoso IM, Lehman FN. 2003. Augmented Gravity Model: An Empirical Application to Mercosur-European Union Trade Flows. Journal of Applied Economics, Vol. VI, No. 2 (Nov 2003), 291-316. 